\title{
Immature stages of beetles representing the 'Opatrinoid' clade (Coleoptera: Tenebrionidae): an overview of current knowledge of the larval morphology and some resulting taxonomic notes on Blapstinina
}

\author{
Marcin Jan Kamiński ${ }^{1,2}$ (D) $\cdot$ Ryan Lumen $^{2} \cdot$ Magdalena Kubicz $^{1} \cdot$ Warren Steiner Jr. $^{3} \cdot \mathrm{Kojun} \mathrm{Kanda}^{2} \cdot$ Dariusz Iwan $^{1}$
}

Received: 8 February 2019 / Revised: 29 March 2019 / Accepted: 1 April 2019 / Published online: 16 April 2019

(c) The Author(s) 2019

\begin{abstract}
This paper summarizes currently available morphological data on larval stages of representatives of the 'Opatrinoid' clade (Tenebrionidae: Tenebrioninae). Literature research revealed that larval morphology of approximately $6 \%$ of described species representing this lineage is currently known (139 out of 2325 spp.). Larvae of the five following species are described and illustrated: Zadenos mulsanti (Dendarini: Melambiina; South Africa), Blapstinus histricus, Blapstinus longulus, Trichoton sordidum (Opatrini: Blapstinina; North America), and Eurynotus rudebecki (Platynotini: Eurynotina; South Africa). The majority of studied larvae were associated with adults using molecular tools, resulting in an updated phylogeny of the 'Opatrinoid' clade. This revised phylogeny provides an evolutionary context for discussion of larval morphology. Based on the morphological and molecular evidence, the following synonym is proposed within Blapstinina: Trichoton Hope, 1841 (=Bycrea Pascoe, 1868 syn. nov.). Based on this decision, a new combination is introduced: Trichoton villosum Pascoe, 1868 comb. nov. The economic importance of the 'Opatrinoid' clade larvae is also briefly discussed, as well as potential future avenues of research.
\end{abstract}

Keywords Darkling beetles $\cdot$ Larval descriptions $\cdot$ Molecular association $\cdot$ Economic importance

\section{Introduction}

Although the importance of larval morphology for understanding the systematics of different groups of Coleoptera has been postulated by many researchers (e.g., Beutel et al. 1999; Grebennikov and Scholtz 2004; Lawrence et al. 2011), for the vast majority of currently known species, there are

Electronic supplementary material The online version of this article (https://doi.org/10.1007/s00435-019-00443-7) contains supplementary material, which is available to authorized users.

Marcin Jan Kamiński

kaminskientomo@gmail.com

1 Zoological Museum, Museum and Institute of Zoology, Polish Academy of Sciences, Wilcza 64, 00-679 Warsaw, Poland

2 Department of Biological Sciences, Northern Arizona University, 617 S. Beaver St, Flagstaff, AZ 86011-5640, USA

3 Department of Entomology, NHB-187, Smithsonian Institution, Washington, DC 20013-7012, USA no available larval descriptions. This also holds true for darkling beetles (Tenebrionidae). The most comprehensive overview of larval morphology within the family was done by Watt (1974), who partly based the modern classification of this group on immature stages. Other important contributions were published by Lawrence (1991) and Matthews et al. (2010). Despite this, comparative analyses of larval features at the lower taxonomic levels (subfamily, tribe, and subtribe) are relatively scarce (however, see Schulze 1963, 1968; Smith et al. 2014). In the majority of cases, such analyses are inhibited by the lack of available larval descriptions or well-preserved material.

Currently, the larval morphology of about $6 \%$ of described species representing the 'Opatrinoid' clade is known (139 out of 2325 spp.; present estimation). The available data do, however, appear to cover most of the currently designated subtribes (Table 1). The majority of available descriptions are of the subtribe Opatrina Brullé, 1832 (54 species). Platynotina Mulsant and Rey, 1853 ranks second (36), and is followed by Helopinina Lacordaire, 1859 
Table 1 Checklist of described larvae of the species representing the 'Opatrinoid' clade

\begin{tabular}{|c|c|c|}
\hline Taxon (\# of larval descriptions/total tribal diversity) & Distribution & Sources \\
\hline \multicolumn{3}{|l|}{ DENDARINI (7/342 sp.) } \\
\hline \multicolumn{3}{|l|}{ I. Dendarina } \\
\hline 1. Dendarus punctatus Mulsant \& Rey, 1853 & Europe & $\begin{array}{l}\text { Byzova and Kelejnikova (1964); Medvedev (1968); Cher- } \\
\text { ney (2005); Skopin (1978) }\end{array}$ \\
\hline 2. Heliopathes avarus Mulsant \& Rey, 1854 & Europe & Skopin (1978) \\
\hline 3. Heliopathes ibericus Mulsant \& Rey, 1854 & Europe & Perris (1877) \\
\hline 4. Phylan abbreviatus (Olivier, 1795) & Europe & Xambeu (1900) \\
\hline 5. Phylan gibbus Fabricius, 1775 & Europe & Perris (1877); Medvedev (1968); Skopin (1978) \\
\hline \multicolumn{3}{|l|}{ II. Melambiina } \\
\hline 1. Allophylax picipes & Europe & Perris (1877) (note); Skopin (1978) \\
\hline 2. Zadenos mulsanti Koch, 1956 & South Africa & This paper \\
\hline \multicolumn{3}{|l|}{ OPATRINI (70/ 2000 sp.) } \\
\hline \multicolumn{3}{|l|}{ I. Ammobiina } \\
\hline 1. Adavius fimbriatus (Ménétries, 1849) & Central Asia & Keleinikova (1968) \\
\hline 2. Ammobius rufus (Lucas, 1846) & Western Palaearctic & Cherney (2005) \\
\hline 3. Caedius maderi Kaszab, 1942 & Japan & Hayashi (1968) \\
\hline \multicolumn{3}{|l|}{ II. Blapstinina Mulsant and Rey, $1853^{\mathrm{a}}$} \\
\hline 4. Blapstinus histricus Casey, 1891 & North America & This paper \\
\hline 5. Blapstinus longulus LeConte, 1851 & North America & This paper \\
\hline 6. Trichoton sordidum (LeConte, 1851) & North America & This paper \\
\hline 7. Trichoton villosum Pascoe, 1868 (comb. nov.) & North and South America & Dugès (1885), Steiner (2004) (photograph) \\
\hline \multicolumn{3}{|l|}{ III. Heterotarsina } \\
\hline 1. Heterotarsus carinula Marseul, 1876 & Japan & Hayashi (1968) \\
\hline \multicolumn{3}{|l|}{ IV. Neopachypterina } \\
\hline- & - & - \\
\hline \multicolumn{3}{|l|}{ V. Opatrina } \\
\hline 1. Anatrum shandanicum Ren, 1999 & China & Yu et al. (2000c) (in Chinese) \\
\hline 2. Eumylada obenbergeri Schuster, 1933 & China & Jinxia and Youzhi (2000) (in Chinese) \\
\hline 3. Eumylada ordosana Reitter, 1889 & China & Jinxia and Youzhi (2000) (in Chinese) \\
\hline 4. Eumylada potanini Reitter, 1889 & China & Jia et al. (2014) (in Chinese) \\
\hline 5. Eumylada punctifera (Reitter, 1889) & Central Asia & Jinxia and Youzhi (2000) (in Chinese) \\
\hline 6. Gonocephalum coriaceum Motschulsky, 1858 & Central Asia & Hayashi (1968) \\
\hline 7. Gonocephalum japanum Motschulsky, 1861 & Japan & Hayashi (1968) \\
\hline 8. Gonocephalum pubiferum Reitter, 1904 & & Yu et al. (2000a) (in Chinese) \\
\hline 9. Gonocephalum pusillum (Fabricius, 1792) & Palearctic Realm & $\begin{array}{l}\text { Lindeman (1889). Ogloblin and Kolobova (1927) } \\
\text { (description); Reichardt (1936) (drawing); Cherney } \\
\text { (2005) }\end{array}$ \\
\hline 10. Gonocephalum pygmaeum (Steven, 1829) & Europe, Asia Minor & Cherney (2005) \\
\hline 11. Gonocephalum recticolle Motschulsky, 1866 & Central Asia & Hayashi (1966) \\
\hline 12. Gonocephalum reticulatus Motschulsky, 1854 & China & Yu et al. (1993) (in Chinese) \\
\hline 13. Gonocephalum rusticum (Olivier, 1811) & Asia, Europe & Keleinikova (1968) \\
\hline 14. Gonocephalum simplex (Fabricius, 1801) & Asia, Africa, Europe & Xambeu (1900), Jack (1917) \\
\hline 15. Gonocephalum subrugulasum Reitter, 1887 & Central Asia and China & Yu et al. (2000a) (in Chinese) \\
\hline 16. Gonocephalum turchestanicum Gridelli, 1948 & Central Asia and Tibet & Yu et al. (2000a) (in Chinese) \\
\hline 17. Jintaium sulcatum Ren, 1999 & China & Li et al. (2013) (in Chinese) \\
\hline 18. Melanesthes csikii Kaszab, 1965 & China & Yu and Ren (1994a, b) (in Chinese) \\
\hline 19. Melanesthes coriaria Reitter, 1904 & Central Asia & Keleinikova 1968 \\
\hline 20. Melanesthes desertora Ren, 1993 & China & Yu and Ren (1994a, b) (in Chinese) \\
\hline 21. Melanesthes exilidentata Ren, 1993 & China & Zhang and Yu (2004) (in Chinese) \\
\hline 22. Melanesthes faldermani Mulsant \& Rey, 1859 & Central Asia & Knor $(1976,1977)$ \\
\hline
\end{tabular}


Table 1 (continued)

\begin{tabular}{|c|c|c|}
\hline Taxon (\# of larval descriptions/total tribal diversity) & Distribution & Sources \\
\hline 23. Melanesthes jenseni Schuster, 1922 & Central Asia & Keleinikova (1968) \\
\hline 24. Melanesthes jintaiensis Ren, 1992 & China & Zhang and Yu (2004) (in Chinese) \\
\hline 25. Melanesthes laticollus (Gebler, 1829) & Central Asia & Keleinikova (1961) \\
\hline 26. Melanesthes maowusuensis Ren, 1992 & China & Yu and Ren (1994a, b) (in Chinese) \\
\hline 27. Melanesthes maxima Menetries, 1854 & Central Asia and China & Yu and Ren (1994a, b) (in Chinese) \\
\hline 28. Melanesthes punctipennis Reitter, 1889 & China & Zhang and Yu (2004) (in Chinese) \\
\hline 29. Melanesthes mongolica Csiki, 1901 & China and Mongolia & Yu and Ren (1994a, b) (in Chinese) \\
\hline 30. Mesomorphus villiger (Blanchard, 1853) & Central Asia and China & Hayashi (1968) \\
\hline 31. Myladina unguiculina Reitter, 1889 & China & Jinxia and Youzhi (2000) (in Chinese) \\
\hline 32. Opatroides punctulatus Brullé, 1832 & Africa, Asia and Europe & Nepesova $(1965)$ \\
\hline 33. Opatrum asperipenne Reitter, 1897 & China & Yu et al. (1993) (in Chinese) \\
\hline 34. Opatrum riparium Scriba, 1865 & Europe, Western Siberia & Byzova and Kelejnikova (1964); Cherney (2005) \\
\hline 35. Opatrum sabulosum (Linnaeus, 1760) & Palearctic Realm & $\begin{array}{l}\text { Schiödte (1878) (description); Lindeman (1889); Ogloblin } \\
\text { and Kolobova (1927) (redescription); Reichardt (1936) } \\
\text { (drawing), Cherney (2005) }\end{array}$ \\
\hline 36. Opatrum subaratum Faldermann, 1835 & China & Yu and Ren (1994a, b) (in Chinese) \\
\hline 37. Opatrum triste Steven, 1829 & Caucasus & Byzova and Kelejnikova (1964); Cherney (2005) \\
\hline 38. Penthicinus koltzei Reitter, 1896 & Uzbekistan and China & Dai et al. (2000) (in Chinese) \\
\hline 39. Penthicus acuticollis Reitter, 1887 & China & Dai et al. (2000) (in Chinese) \\
\hline 40. Penthicus alashanicus Reichardt, 1936 & China and Mongolia & Dai et al. (2000) (in Chinese) \\
\hline 41. Penthicus altaicus (Gebler, 1829) & Asia & Keleinikova (1968) \\
\hline 42. Penthicus auliensis (Reitter, 1904) & Central Asia & Keleinikova (1968) \\
\hline 43. Penthicus explanatus Reitter, 1896 & Central Asia & Knor $(1976,1977)$ \\
\hline 44. Penthicus gibbus (Falderman, 1835) & Central Asia & Knor (1978) \\
\hline 45. Penthicus granulosus (Ménétriès, 1849) & Central Asia & Keleinikova (1968) \\
\hline 46. Penthicus kiritshienkoi Reichardt, 1936 & China and Mongolia & Yu and Ren (1994a, b) (in Chinese) \\
\hline 47. Penthicus nanshanicus Reichardt, 1936 & China and Mongolia & Li et al. (2013) (in Chinese) \\
\hline 48. Penthicus rufescens (Mulsant \& Rey, 1859) & Central Asia & Keleinikova (1968) \\
\hline $\begin{array}{l}\text { 49. Penthicus tannuolensis Medvedev \& Mordkovich } \\
1970\end{array}$ & Central Asia & Knor (1978) \\
\hline 50. Sinorus colliardi (Fairmaire, 1860) & France and Italy & Perris (1877) \\
\hline 51. Scleropatrum csikii (Kaszab, 1967) & China & Yu et al.( 2000b) (in Chinese) \\
\hline 52. Scleropatrum horridum Reitter, 1898 & China and Mongolia & Yu et al.( 2000b) (in Chinese) \\
\hline 53. Scleropatrum prescotti (Faldermann, 1833) & China and Mongolia & Knor (1976) \\
\hline 54. Scleropatrum tuberculatum Reitter, 1887 & China & Yu et al.(2000b) (in Chinese) \\
\hline \multicolumn{3}{|l|}{ VI. Sclerina } \\
\hline- & - & - \\
\hline \multicolumn{3}{|l|}{ VII. Stizopina } \\
\hline 1. Amathobius mesoleius Gebien, 1920 & Southern Africa & Schulze (1963) \\
\hline 2. Eremostibes barbatus Koch, 1963 & Southern Africa & Schulze 1963) \\
\hline 3. Eremostibes opacus Koch, 1963 & Southern Africa & Schulze 1963) \\
\hline 4. Nemanes expansicollis Fairmaire, 1888 & Southern Africa & Schulze (1963) \\
\hline 5. Parastizopus armaticeps (Péringuey, 1892) & Southern Africa & Schulze (1963) \\
\hline \multicolumn{3}{|l|}{ 6. Parastizopus caraboides (Fairmaire, 1897) } \\
\hline 7. Periloma alfkeni Gebien, 1938 & Southern Africa & Schulze (1963) \\
\hline 8. Psammogaster malani Koch, 1953 & Southern Africa & Schulze (1963) \\
\hline \multicolumn{3}{|l|}{ PEDININI (23/ 290 sp.) } \\
\hline \multicolumn{3}{|l|}{ I. Leichenina } \\
\hline $\begin{array}{l}\text { 1. Leichenum canaliculatum variegatum (Klug, } \\
\text { 1833) }\end{array}$ & Afrotropical Realm & St. George (1930); Dunford and Steiner (2007) \\
\hline
\end{tabular}


Table 1 (continued)

\begin{tabular}{|c|c|c|}
\hline Taxon (\# of larval descriptions/total tribal diversity) & Distribution & Sources \\
\hline 2. Leichenum pictum (Fabricius, 1801) & Europe & Cherney (2005) \\
\hline \multicolumn{3}{|l|}{ II. Helopinina } \\
\hline 1. Aptila noxia Fåhræus, 1870 & South Africa & Schulze (1968) \\
\hline 2. Diestecopus sp. & South Africa & Schulze (1968) \\
\hline 3. Drosochrus meruensis Gebien, 1910 & South Africa & Schulze (1968) (1st instar) \\
\hline 4. Drosochrus kochi Schulze, 1968 & South Africa & Schulze (1968) \\
\hline 5. Drosochrus textor Schulze, 1968 & South Africa & Schulze (1968) \\
\hline 6. Drosochrus tristis Fåhræus, 1870 & South Africa & Jack (1917) \\
\hline 7. Micrantereus femoratus Gerstaecker, 1873 & South Africa & Schulze (1968) (key) \\
\hline 8. Micrantereus hirsutus Péringuey, 1904 & South Africa & Schulze (1968) (key) \\
\hline 9. Micrantereus longipes (Fåhraeus, 1870) & South Africa & Schulze (1968) (1st instar) \\
\hline 10. Micrantereus paulschulzei Schulze, 1968 & South Africa & Schulze (1968) (1st instar) \\
\hline 11. Micrantereus scaberrimus Fairmaire, 1894 & South Africa & Schulze (1968) \\
\hline 12. Micrantereus spissus Péringuey, 1899 & South Africa & Schulze (1968) (key) \\
\hline \multicolumn{3}{|l|}{ III. Pedinina } \\
\hline 1. Cabirutus obtusicollis (Reitter, 1891) & Central Asia & Keleinikova (1966) \\
\hline 2. Cabirutus pusillus (Menetries, 1849) & Central Asia & Keleinikova 1966; Medvedev (1968) \\
\hline 3. Pedinus borysthenicus Reichardt, 1936 & Europe & Medvedev (1968); Cherney 2005 \\
\hline 4. Pedinus cimmerius cimmerius Medvedev, 1968 & Europe & Cherney (2005) \\
\hline 5. Pedinus cimmerius znoikoi Medvedev, 1968 & Europe & Cherney (2005) \\
\hline 6. Pedinus femoralis (Linnaeus, 1767) & Palearctic Realm & $\begin{array}{l}\text { Lindeman (1889); Keleinikova (1966); Medvedev (1968); } \\
\text { Cherney (2005); Skopin (1978) }\end{array}$ \\
\hline 7. Pedinus tauricus Mulsant \& Rey, 1853 & Middle East & Cherney (2005) \\
\hline 8. Pedinus strigicollis Reitter, 1904 & & Cherney (2005) \\
\hline 9. Pedinus strigosus Faldermann, 1835 & China & Yu et al. (1993) \\
\hline \multicolumn{3}{|l|}{ PLATYNOTINI (39/493 sp.) } \\
\hline \multicolumn{3}{|l|}{ I. Eurynotina } \\
\hline 1. Eurynotus capensis (Fabricius, 1794) & South Africa & Tschinkel (1978) (ovoviviparity) \\
\hline 2. Eurynotus rudebecki Koch, 1955 & South Africa & This paper \\
\hline 3. Heteropsectropus sp. & South Africa & Schulze (1969) (habitus photo) \\
\hline \multicolumn{3}{|l|}{ II. Platynotina } \\
\hline 1. Alaetrinus minimus (Palisot de Beauvois, 1805) & USA & Iwan (1995) \\
\hline 2. Alaetrinus aciculatus Le Conte, 1859 & USA & Iwan (1995) \\
\hline 3. Anchophthalmus algoensis Péringuey, 1904 & Southern Africa & Iwan and Schimrosczyk (2008) \\
\hline 4. Anchophthalmus silphoides Gerstaecker, 1854 & Southern Africa & Iwan and Banaszkiewicz (2005) \\
\hline 5. Anomalipus acutangulus Oertzen, 1897 & Zimbabwe & Iwan and Banaszkiewicz (2005) \\
\hline 6. Anomalipus braini Endrödy-Younga, 1988 & Zimbabwe & Iwan and Banaszkiewicz (2005) \\
\hline $\begin{array}{l}\text { 7. Anomalipus elephas tibialis Endrödy-Younga, } \\
1988\end{array}$ & Southern Africa & Iwan and Banaszkiewicz (2005) \\
\hline $\begin{array}{l}\text { 8. Anomalipus expansicollis thoracicus Oertzen, } \\
1897\end{array}$ & Southern Africa & Iwan and Banaszkiewicz (2005) \\
\hline 9. Anomalipus mastodon Fåhraeus, 1870 & Southern Africa & Iwan and Banaszkiewicz (2005) \\
\hline 10. Anomalipus meles Fåhraeus, 1870 & Southern Africa & Iwan and Banaszkiewicz (2005) \\
\hline 11. Anomalipus multilineatus (Horn, 1866) & Southern Africa & Iwan and Banaszkiewicz (2005) \\
\hline 12. Anomalipus planus Fåhraeus, 1870 & Southern Africa & Iwan and Banaszkiewicz (2005) \\
\hline 13. Anomalipus plebejus Péringuey, 1896 & Zimbabwe & $\begin{array}{l}\text { Jack (1917), Iwan and Bečvář (2000), Iwan and Banaszk- } \\
\text { iewicz (2005) }\end{array}$ \\
\hline 14. Anomalipus sculpturatus Péringuey, 1886 & Southern Africa & Iwan and Banaszkiewicz (2005) \\
\hline 15. Anomalipus seriatus Oertzen, 1897 & Southern Africa & Iwan and Banaszkiewicz (2005) \\
\hline 16. Anomalipus urus Fåhraeus, 1870 & Southern Africa & Iwan and Banaszkiewicz (2005) \\
\hline
\end{tabular}


Table 1 (continued)

\begin{tabular}{|c|c|c|}
\hline Taxon (\# of larval descriptions/total tribal diversity) & Distribution & Sources \\
\hline 17. Bantodemus zulu Koch, 1955 & Southern Africa & Schulze (1964) \\
\hline 18. Clastopus aberlenci Iwan, 2005 & Madagascar & Iwan (2005) (ovoviviparity) \\
\hline 19. Glyptopteryx femineus (Lesne, 1922) & Southern Africa & Schulze (1964) \\
\hline 20. Gonopus agrestis Fåhraeus, 1870 & Southern Africa & Schulze $(1962,1978)$ \\
\hline 21. Gonopus angusticostis Gebien, 1920 & Southern Africa & Schulze (1978) \\
\hline 22. Gonopus hirtipes Fåhraeus, 1870 & Southern Africa & Schulze (1978) \\
\hline 23. Gonopus pliciventris Gebien, 1920 & Southern Africa & Schulze (1978) \\
\hline 24. Gonopus tibialis Fabricius, 1798 & Southern Africa & Schulze $(1962,1978)$ \\
\hline 25. Gonopus transvaalensis Schulze, 1976 & Southern Africa & Schulze (1978) \\
\hline 26. Melanocratus ferreri Iwan, 1996 & Madagascar & Iwan (2000) (ovoviviparity) \\
\hline 27. Melanopterus marginicollis Mulsant \& Rey, 1854 & South Africa & Tschinkel (1978) (ovoviviparity) \\
\hline 28. Opatrinus gibbicollis Mulsant \& Rey, 1853 & Panama & Iwan (1995) \\
\hline 29. Pseudoblaps ampliata Fairmaire, 1898 & Nepal & Skopin (1972) \\
\hline 30. Sebastianus major (Fairmaire, 1899) & Madagascar & Iwan (2005) (ovoviviparity) \\
\hline 31. Sebastianus ovoideus (Fairmaire, 1902) & Madagascar & Iwan (2005) (ovoviviparity) \\
\hline 32. Sebastianus projectus Iwan, 1996 & Madagascar & Iwan (2000) (ovoviviparity) \\
\hline 33. Sebastianus simplex Iwan, 1996 & Madagascar & Iwan (2000) (ovoviviparity) \\
\hline 34. Styphacus bartolozzi Iwan, 1996 & Madagascar & Iwan (2000) (ovoviviparity) \\
\hline 35. Styphacus kochi Iwan, 1996 & Madagascar & Iwan (2000) (ovoviviparity) \\
\hline 36. Zophodes fitzsimonsi Koch, 1956 & Southern Africa & Schulze (1964) \\
\hline
\end{tabular}

${ }^{a}$ Marcuzzi and Cravera (1981) described the larval morphology of seven following Blapstinina species: Blapstinus dominicus Marcuzzi, 1962, Blapstinus marcuzzii Aalbu, 2017, Blapstinus puertoricensis (Marcuzzi, 1977), Diastolinus clavatus Mulsant and Rey, 1859, Diastolinus perforatus (Schönherr, 1806), Xerolinus minor (Marcuzzi, 1977), and Xerolinus sallei (Mulsant and Rey, 1859). However, according to more recent contributions, due to the massive misidentifications discovered in Marcuzzi's papers, the associations of those larvae can't be confirmed (Hart \& Ivie 2016, Ivie \& Hart 2016)

(12), Pedinina Eschscholtz, 1829 (9) Stizopina Lacordaire, 1859 (8), Dendarina Mulsant and Rey, 1854 (5), Blapstinina Mulsant and Rey, 1853 (1, plus 3 described below), Ammobiina Desbrochers des Loges, 1902 (3), Leichenina Mulsant, 1854 (2), Eurynotina Mulsant and Rey, 1854 and Melambiina Mulsant and Rey, 1854 (both 1 and 1 described below), and Heterotarsina Blanchard, 1845 (1). No larval descriptions are available for Neopachypterina Bouchard et al. 2007 and Sclerina Lacordaire, 1859 (Table 1). It should be noted that, in the case of Platynotini (i.e., Eurynotina and Platynotina), some of the contributions concern early instar larvae extracted from the bursa copulatrix (Tschinkel 1978; Iwan 2005).

The most comprehensive discussion of opatrinoid larval characters in a wider phylogenetic context was presented by Iwan and Bečvář (2000), who largely focused on the evaluation of different classification concepts developed for tenebrionidae larvae (Skopin 1962, 1964; Watt 1974). Valuable contributions were also published by Medvedev (1968) and Schulze (1963, 1969). However, due to a lack of phylogenetic studies concerning opatrinoid beetles, all of the above-mentioned papers have dealt with slightly different, paraphyletic entities [Opatrinae sensu Koch (1956) or Medvedev (1968)]. A phylogeny-based classification of the 'Opatrinoid' clade was introduced recently
(Iwan and Kamiński 2016; Kamiński et al. 2018a, 2019). This reclassification provided an opportunity to revise the available knowledge on larval morphology in a new context. Moreover, recent rearing efforts provided larvae of taxa representing subtribes for which few, or no immature stages were previously described.

The main aim of this paper is to summarize current morphological knowledge on the larval stages representing the 'Opatrinoid' clade, and to discuss its relevance for understanding the phylogeny of the group. Moreover, based on some newly accessed material, larvae of the following five species are described: Zadenos mulsanti Koch, 1956 (Dendarini: Melambiina; South Africa), Blapstinus histricus Casey, 1890 (Opatrini: Blapstinina; North America), Blapstinus longulus LeConte, 1851 (Opatrini: Blapstinina; North America), Trichoton sordidum (LeConte, 1851) (Opatrini: Blapstinina; North America), and Eurynotus rudebecki Koch, 1955 (Platynotini: Eurynotina; South Africa). 


\section{Materials and methods}

This is the second and final paper of a series focused on immature stages of beetles representing the 'Opatrinoid' clade (Coleoptera: Tenebrionidae). For part one, concerning the pupal stages, and the phylogenetic background see Kamiński et al. (2018b).

\section{Material}

The larval specimens of the two analysed Afrotropical species (Eurynotus rudebecki Koch, 1955 and Zadenos mulsanti Koch, 1956) were bred from imagines collected in the surroundings of Mossel Bay (South Africa) (see Fig. 1 in Kamiński et al. 2018b). Adults of both species were placed in terraria filled to a depth of $\sim 10 \mathrm{~cm}$ with sand. Leaves of red clover were provided as a food resource. Terraria were watered every 2 weeks. Larvae were collected after 2 months from the beginning of the experiment. Obtained specimens were stored in $98 \%$ ethanol in $-20{ }^{\circ} \mathrm{C}$. In the case of Z. mulsanti, a single specimen pupated (Kamiński et al. 2018b). The above-mentioned breeding efforts were conducted by MJK.

Trichoton sordidum larvae were bred in two attempts. For the first, approximately 100 individuals (not sorted by sex) were introduced into containers $(22 \mathrm{~cm} \times 40 \mathrm{~cm} \times 30 \mathrm{~cm})$ filled to a depth of $\sim 5 \mathrm{~cm}$ with a 50/50 mix of Imagitarium Calcium Sand (from PetCo) and fine-grain, baked Mojave Desert Sand. Two medium sized, flat rocks were provided as sites for beetles to hide. The colony was watered 2-3 times per week. Zucchini was provided as a food resource (replaced when consumed or dried up). Ambient room temperature was kept in the range of 21.6-23.8 ${ }^{\circ} \mathrm{C}$. Substrate was sifted once per month. Although many mating specimens were immediately observed, no larvae were observed for 2 months. The first larvae were detected after approximately 3-4 months. Specimens were taken for preservation, as survivorship to pupation/adulthood was uncertain. No larvae survived or pupated.

Blapstinus longulus, B. histricus, and a second attempt of Trichoton sordidum larvae were reared following the methods of Zilkowski and Cossé (2015). Trichoton sordidum adults (ca. 70-80 specimens) from the first attempt were used for the second. Blapstinus longulus and B. histricus were collected and introduced into similarly prepared containers. Halved apples were provided for food and as a water source (wet side down) on the surface of the wood shavings, and changed out every 7-9 days to prevent molding. Containers were checked every 2 weeks for larvae. After 3 weeks, larvae were detected in both Blapstinus containers, and representatives were taken for preservation on the fifth week. Trichoton larvae were detected after a month, and specimens were taken for preservation immediately, as survivorship was low in the previous attempt. Specimens selected for the molecular analysis were stored in $98 \%$ ethanol in $-20{ }^{\circ} \mathrm{C}$, other individuals were boiled in water briefly and were then preserved with 98\% ethanol. Breeding efforts concerning the representatives of Blapstinina were done by RL.

Adult specimens used for breeding were identified using Koch (1954, 1955, 1956), Davis (1970), and Arnett and Thomas (2002).

\section{Molecular association}

Because E. rudebecki and Z. mulsanti were bred in a single terrarium, molecular techniques were required to separate the obtained larvae. As well, to confirm the identity of the Blapstinus larvae, the same approach was employed. The larvae of Trichoton sordidum were not included in molecular analyses due to scarcity of the obtained larvae (see below). However, adults of T. sordidum were processed to test the phylogenetic position of Trichoton. Finally, as there is now a more recent molecular phylogeny of the 'Opatrinoid' clade to compare to, the molecular data obtained here can be integrated for further study of the group (Fig. 2).

DNA was extracted from ethanol-preserved specimens using DNeasy Blood and Tissue kits (Qiagen), following the manufacturer's protocols. Extractions were performed on disarticulated specimens. Efforts were taken to amplify and sequence DNA for six gene fragments: 12S rRNA (12S, 354 bp), 28S rRNA (28S, 1057 bp) D1-D3, cytochrome c oxidase subunit II (COII, 654 bp), wingless (wg, 435 bp), CAD/rudimentary (CAD2, 723 bp), and arginine kinase (ArgK, $669 \mathrm{bp}$ ). This set of markers fully corresponds to those used in the only available phylogeny of the 'Opatrinoid' clade (Kamiński et al. 2019). For primers' specification and details concerning the PCR reactions, see Kamiński et al. (2019) and Kanda et al. (2015, 2016). Molecular analysis of the South African species was done at the Museum and Institute of Zoology of the Polish Academy of Sciences (MIIZ), while the representatives of Blapstinina were processed at the Northern Arizona University (NAU). Sequences were aligned using Mesquite (Maddison and Maddison 2016). All nucleotide alignments were combined into a single concatenated data set for phylogenetic analyses. Optimal data partitions and models of molecular evolution were inferred using PartitionFinder v. 2.1.1 (Lanfear et al. 2012). The phylogenetic tree 


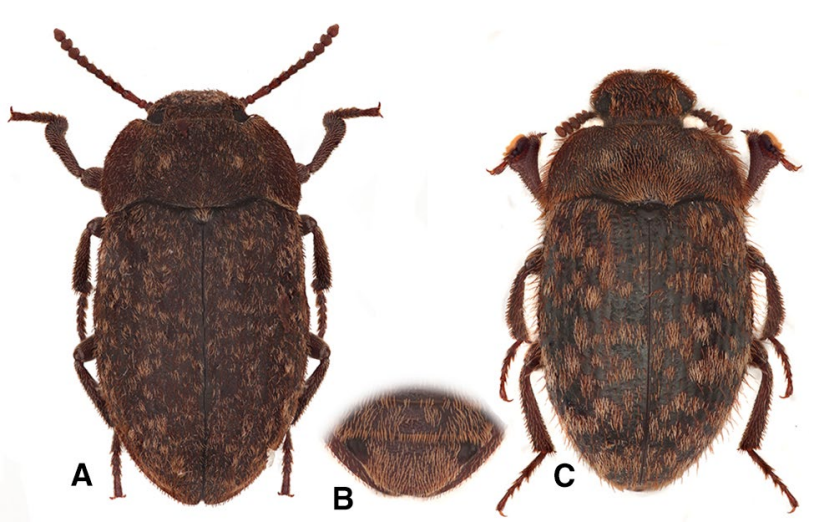

Fig. 1 Morphology of the selected Trichoton sensu novum species: a, b $T$. sordidum and $\mathbf{c} T$. villosum. Image $\mathbf{b}$ illustrates a newly proposed diagnostic character (glabrous and depressed basal angles of fifth abdominal ventrite)

was constructed under Maximum Likelihood estimation using RAxML v. 8 (Stamatakis 2014). Analysis was conducted on servers maintained by the CIPRES Scientific Gateway (Miller et al. 2010).

\section{Larval descriptions}

Nomenclature and descriptions follow that of Smith et al. (2014). However, modifications were made to reflect the specific morphology of the 'Opatrinoid' clade larvae (see Schulze 1968; Iwan 1995; Iwan \& Bečváŕ 2000). Descriptions were based only on mature larvae, i.e., large specimens (one to two instars prior the pupation). Total length (TL) of analysed specimens was measured from the anterior edge of the clypeus to the apex of abdominal segment IX. Head capsule width (HW) was measured dorsally across the widest portion of the head. Prothoracic width (PW) and length (PL) were also measured dorsally across the widest and longest points on the segment, respectively. Images were taken using a Canon 1000D body with accordion bellows and a Canon Macro Lens EF 100 mm, and with a Hitachi S-3400 N SEM at MIIZ.

\section{Results}

\section{DENDARINI: Melambiina}

Genus Zadenos Laporte, 1840

Zadenos mulsanti Koch, 1956

Material examined Larvae were reared from adults with the following collecting information: "Mossel Bay,
South Africa, -34.147305, 22.065792, 9.1.2017, leg. M.J. Kamiński \& A.D. Smith". A total of 20 larvae were reared and examined for this study. Selected specimens were preserved at the entomological collection of the Museum and Institute of Zoology, Polish Academy of Sciences. GenBank accession numbers: MK714051, MK714054, MK714071 (larva).

Differential diagnosis See discussion under Dendarini.

Description TL: $15.0-18.5 \mathrm{~mm}$, HW: $1.3-1.5 \mathrm{~mm}$, PL: $1.2-1.3 \mathrm{~mm}$, PW: $1.6-1.8 \mathrm{~mm}, \mathrm{PL} / \mathrm{mes}$ othoracic length $=1.6 ; \mathrm{PL} / \mathrm{mesothoracic}$ length $=1.2-1.3$.

Head Prognathous, distinctly retracted into prothorax; head capsule weakly dorsoventrally flattened; width nearly equal to prothorax; sides rounded; strongly constricted before occipital foramen; yellow with brown spots, same as body segments; punctation absent. Epicranial suture stem length approximately one-third head capsule length; frontal arms sinuate, double branched apically, not reaching epistomal margin. Frons almost smooth, without visible microsculpture, with pair of deep setose points at apex (Fig. 4a). Epicranial plates almost smooth dorsally, without microsculpture; each plate with deep depressions with single long setae in middle and apex; lateral portions sparsely setose (several long setae present); ventral portion of each plate with row of 2-3 long setae along anterior margin near buccal cavity, not confluent with setae on lateral portions of plates (Fig. 4b). Four stemmata present on each epicranial plate, pigmented and well visible. Clypeus trapezoidal, with four deep setose points of which two are located medially while remaining two laterally (Fig. 4a). Labrum transverse, weakly emarginate, medially with pair of long setae, apical margin with row of eight setae. Epipharynx similar as in Eurynotus rudebecki (Fig. 6f). Mandibles asymmetrical, their bifid apices strongly sclerotised and dark; right mandible with triangular premolar tooth. Labium with distinct prementum, mentum and submentum; gula apically well developed, elongated and rectangular; subquadrate prementum, with pair of setae basally and additional one in middle, ligula reduced (Fig. 4c), about $0.2 \times$ of width of first labial segment, labial palps 2-segmented; mentum elongated, hexagonal, with elongated setae distributed in middle; trapezoidal submentum with row of four setae in middle (Fig. 4b). Hypopharyngeal sclerome trilobed, with apical denticle strongly elongated (Fig. 4d). Maxillary palpi 3-segmented, first and third segments of same length, second one about 1.2 longer. Antennae 3 -segmented, second antennomere is 3.0 times longer than wide, same length as the first. 


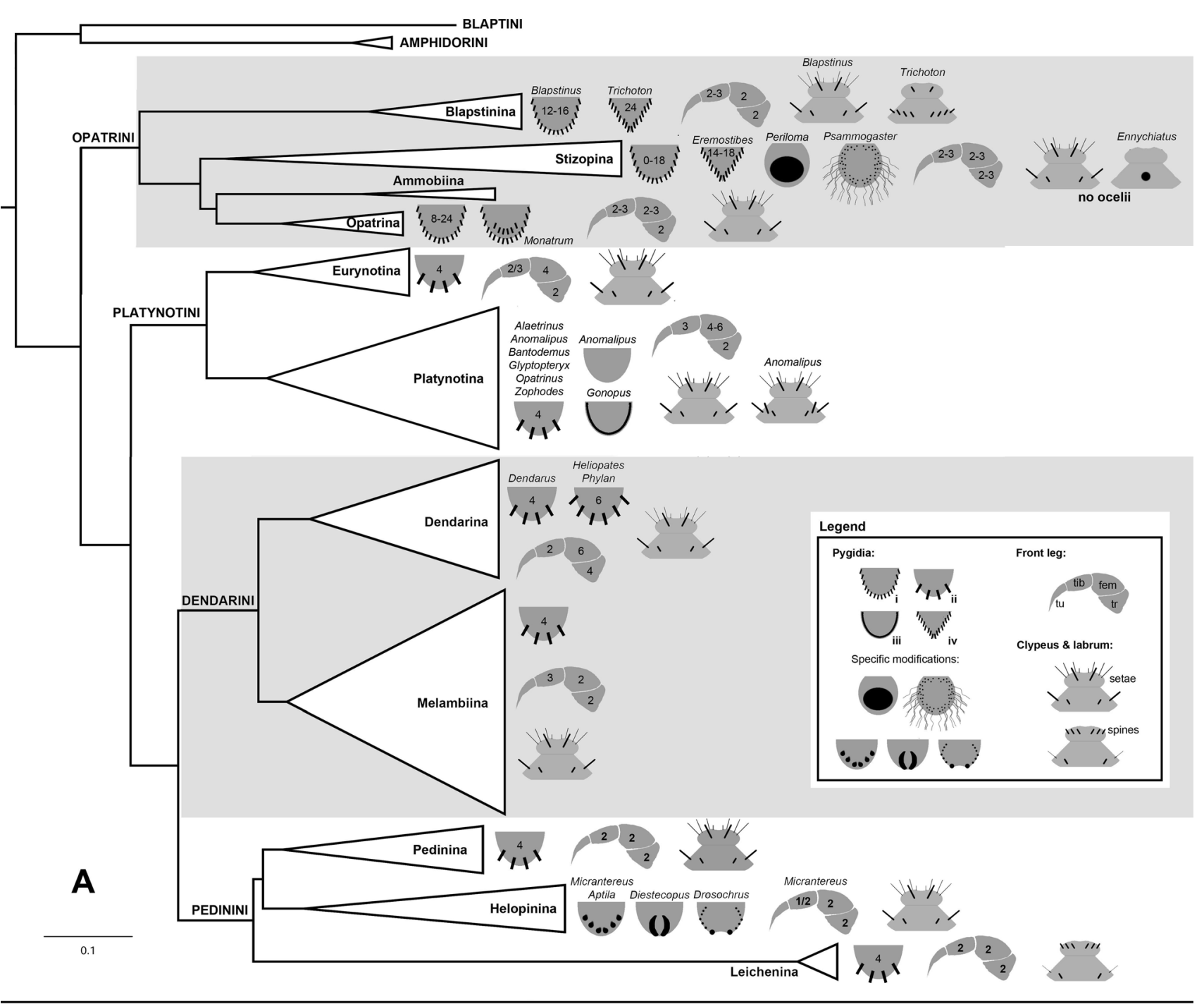

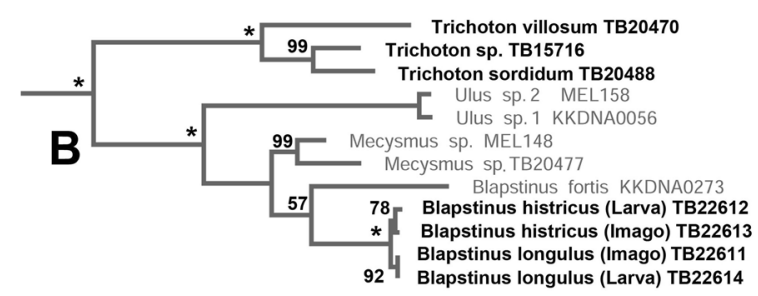

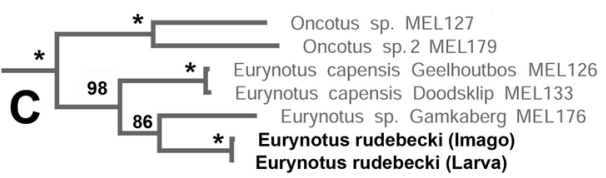

Fig. 2 Phylogenetic relations within the 'Opatrinoid' clade: a variability of the selected larval features presented on the simplified phylogeny. b-d Maximum likelihood trees of concatenated data set confirming the association of the studied larvae: b Blapstinina, c Eurynotina, and d Melambiina. (1) Rounded (in dorsal view) pygidium with several short spines [state commonly observed in Opatrini and Amphidorini, Fig. 5b, f; (2) with four or six elongated spines [common in Dendarini, Pedinini. Platynotini, Figs. 4g,6i; (3) without

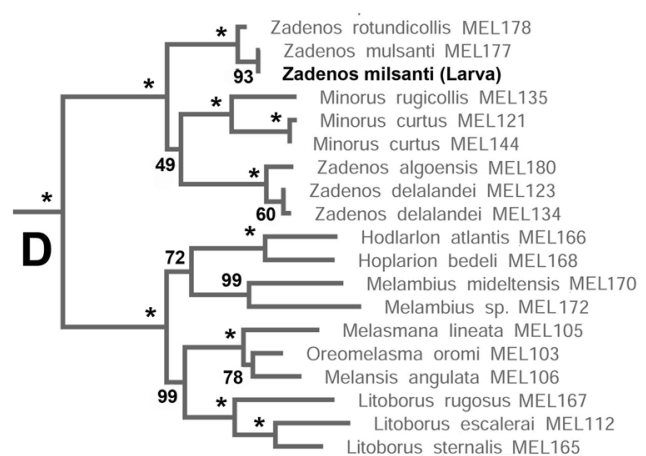

spines, with a rim at the lateral and basal edges [state characteristic for the genus Gonopus]; (4) triangular pygidium with several short spines (common in Opatrini, Fig. 5k); (tu) protarsungulus, (tib) protibia, (fem) profemur, (tr) protrochanter; Asterik indicates maximum likelihood bootstrap percentage of $100 \%$ boot support of a particular clade (other percentage values are indicated by numbers on particular branches). Newly added OTUs were marked with black. For phylogenetic details see Kamiński et al. (2019) 


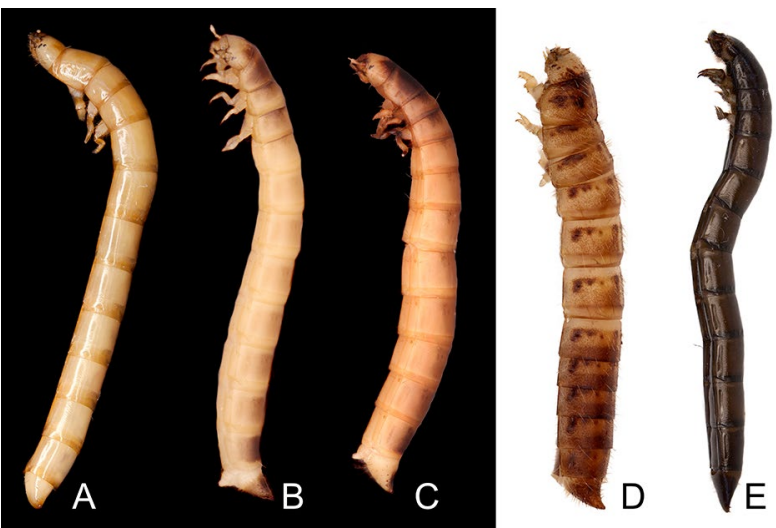

Fig. 3 Lateral habitus of five larvae representing the 'Opatrinoid' clade: a Zadenos mulsanti (Dendarini: Melambiina), b Blapstinus histricus (Opatrini: Blapstinina), c Blapstinus longulus (Opatrini: Blapstinina), d Trichoton sordidum (Opatrini: Blapstinina), and e Eurynotus rudebecki (Platynotini: Eurynotina)

Thorax Thoracic tergites yellow with brownish bands in apical part (Fig. 3a). Prothoracic tergum subquadrate, about $2 \times$ length of meso- and $1.4 \times$ metaterga. Meso- and metathoracic tergites wider than long. Thoracic tergites sparsely setose on dorsal surfaces. Mesothoracic spiracle simple, ovate, approximately $1.5 \times$ size of abdominal spiracles; metathoracic spiracle reduced. Thoracic sternites densely covered by microtrichia. Legs. Prothoracic leg noticeably longer, much thicker than meso- and metathoracic ones; prothoracic tarsungulus strongly sclerotized, spade-like; prothoracic trochanter with two stout spines ventroapically; prothoracic femur with ventromedial row of two spines; prothoracic tibia with ventromedial row of three spines (Fig. 4e). Prothoracic tarsungulus about $0.8 \times$ length of tibia; same length as trochanter. Mesotibia with two or three ventromedial spines.

\begin{abstract}
Abdomen Abdominal tergites yellow with brownish bands on apex, faintly rugose, without setation. Abdominal sternite I with path of setae basally. Pygidium triangular, urogomphi absent; marginal row of four socketed spines present, arranged as single row around posterior edge; basal row composed of several soft setae (Fig. 4g). Pygopods short, subconical (Fig. 4f).
\end{abstract}

\section{OPATRINI: Blapstinina}

Genus Blapstinus Dejean, 1821

Blapstinus histricus Casey, 1891
Material examined Larvae were reared from adults with the following collecting information: "Canoa Ranch Rest Area, Pima County, Arizona 3-4 Aug 2018 (R.Lumen, K.Kanda)". More than 100 larvae were reared and examined for this study. Selected specimens were preserved at the entomological collection of the Museum and Institute of Zoology, Polish Academy of Sciences. GenBank accession numbers: MK714042, MK714055, MK714062 (larva), MK714043, MK714056, MK714063 (imago).

Differential diagnosis See diagnosis of Blapstinus longulus.

Description TL: $9.5-12.0 \mathrm{~mm}$, HW: $0.7-0.8 \mathrm{~mm}$, PL: 1.0 $1.1 \mathrm{~mm}$, PW: $1.0-1.1 \mathrm{~mm}$, PL/mesothoracic length $=1.3$; $\mathrm{PL} / \mathrm{mesothoracic}$ length $=1.5$.

Head Prognathous, distinctly retracted into prothorax; weakly dorsoventrally flattened; width nearly equal to prothorax; sides rounded; strongly constricted before occipital foramen; yellow, with two nearly confluent brown spots covering epicranial plates (Fig. 5a); punctation absent or extremely fine. Epicranial suture stem length approximately one-third head capsule length; frontal arms sinuate, extend to antennal insertion. Frons faintly rugose, with microsculpture. Epicranial plates weakly rugose dorsally, with microsculpture; each plate with deep setose point in middle; lateral portions moderately setose (11-13 setae present); ventral portion of each plate with row of three-to-four long setae along anterior margin near buccal cavity, not confluent with setae on lateral portions of plates. Two stemmata present on each epicranial plate, pigmented and well visible. Clypeus trapezoidal, slightly darker medially, with four deep setose points of which two are located medially and two laterally. Labrum transverse, weakly emarginate, with apical row of elongated setae. Epipharynx anterolateral margins with six spinose setae; four subanterior sensory papillae present, arranged as transverse row subtended by two spinose setae. Mandibles asymmetrical, their bifid apices strongly sclerotised and dark; left mandible with triangular premolar tooth and two distinct apical teeth; right mola reduced, with single apical tooth. Labium with distinct prementum, mentum and submentum; gula well developed, elongated and rectangular; subquadrate prementum bears pair of setae in center, ligula twice shorter narrower than first labial segment, labial palps 2-segmented; mentum elongated, with pair of setae at base and 2 pairs of longer setae lateromedially; trapezoidal submentum bears pair of setae basaly. Hypopharyngeal sclerome pentagonal; tricuspidate, with apical denticle elongated; with deep depression in middle. Maxillary palpi 3 -segmented, first and third segments of same length, second one about 1.2 longer. Antennae 3-segmented, second antennomere is 2.0 times longer than wide and about 2 times longer than first (Fig. 5a). 
Fig. 4 Larval morphology of Zadenos mulsanti: a head in dorsal view, b mouthparts in ventral view, $\mathbf{c}$ close-up of ligula, d hypopharyngeal sclerome, $\mathbf{e}$ front leg, $\mathbf{f}$ pygopods, g pygidium. $a 9$ abdominal segment IX
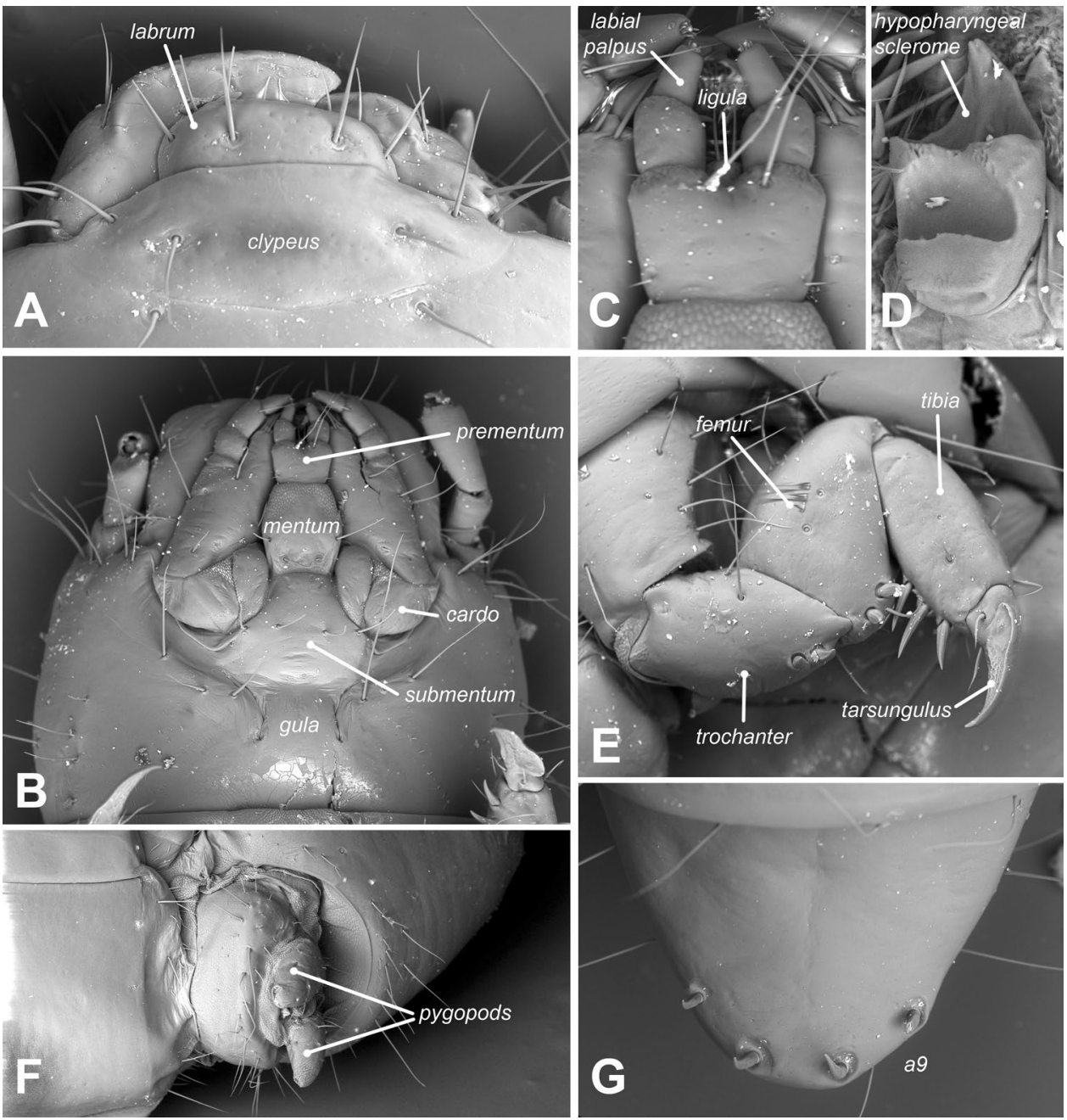

Thorax Thoracic tergites yellow, covered with brown spots (Figs. 3b,5a). Prothoracic tergum subquadrate, about $2 \times$ length of meso- or metaterga; dorsally covered with single brown spot. Meso- and metathoracic tergites wider than long, apically each with brown band. Brown spots of thoracic segments narrowly interrupted medially. Thoracic tergites sparsely setose on dorsal surfaces. Lateral margin of protergum with eight to ten long setae in anterior part. Mesothoracic spiracle simple, ovate, approximately $1.5 \times$ size of abdominal spiracles; reduced metathoracic spiracle visible. Legs. Prothoracic leg slightly longer, thicker than mesoand metathoracic legs; prothoracic tarsungulus sclerotized; prothoracic trochanter with two stout spines ventroapically; prothoracic femur and tibia with ventromedial row of two spines. Prothoracic tarsungulus about $0.5 \times$ length of femur and tibia; about $0.7 \times$ length of trochanter. Mesotibia with two ventromedial spines.

Abdomen Abdominal tergites yellow, faintly rugose, with sparse elongate seate laterally. Abdominal sternite I with narrow brown band in apical part. Abdominal laterotergites with lateral margins indistinctly pigmented. Abdominal segment VIII with row of four setae basally, entirely covered by brownish spot. Pygidium rounded apically; with wide brown band (Fig. 5b); suddenly upturned to apex, urogomphi absent; marginal row of 12-16 socketed spines present, arranged as single row around posterior two-thirds to one half of segment (Fig. 5c); basal row of eight soft setae located outside of brown spot. Pygopods short, subconical.

\section{Blapstinus longulus LeConte, 1851}

Material examined Larvae were reared from adults with the following collecting information: "Sunset Point Rest Area, Yavapai County, Arizona 25 July, 2018 (R. Lumen, E. Lumen, A.L. Smith)". More than 100 larvae were reared and examined for this study. Selected specimens were preserved at the entomological collection of the Museum and Institute of Zoology, Polish Academy of Sciences. GenBank 
Fig. 5 Morphology of the analysed larvae representing Blapstinina: a-c Blapstinus histricus, $\mathbf{d}-\mathbf{g}$ Blapstinus longulus, $\mathbf{h}-\mathbf{k}$ Trichoton sordidum. a, e, i Head and thoracic segments in dorsal view, $\mathbf{h}$ tip o head in dorsal view, $\mathbf{d}$ mouthparts in ventral view, abdominal segments in $(\mathbf{b}, \mathbf{c}, \mathbf{f}, \mathbf{k}, \mathbf{j})$ dorsal and $(\mathbf{g})$ lateral views. a1-a9 Abdominal segments I-IX; $\mathrm{t} 1-\mathrm{t} 3$ thoracic segments I-III
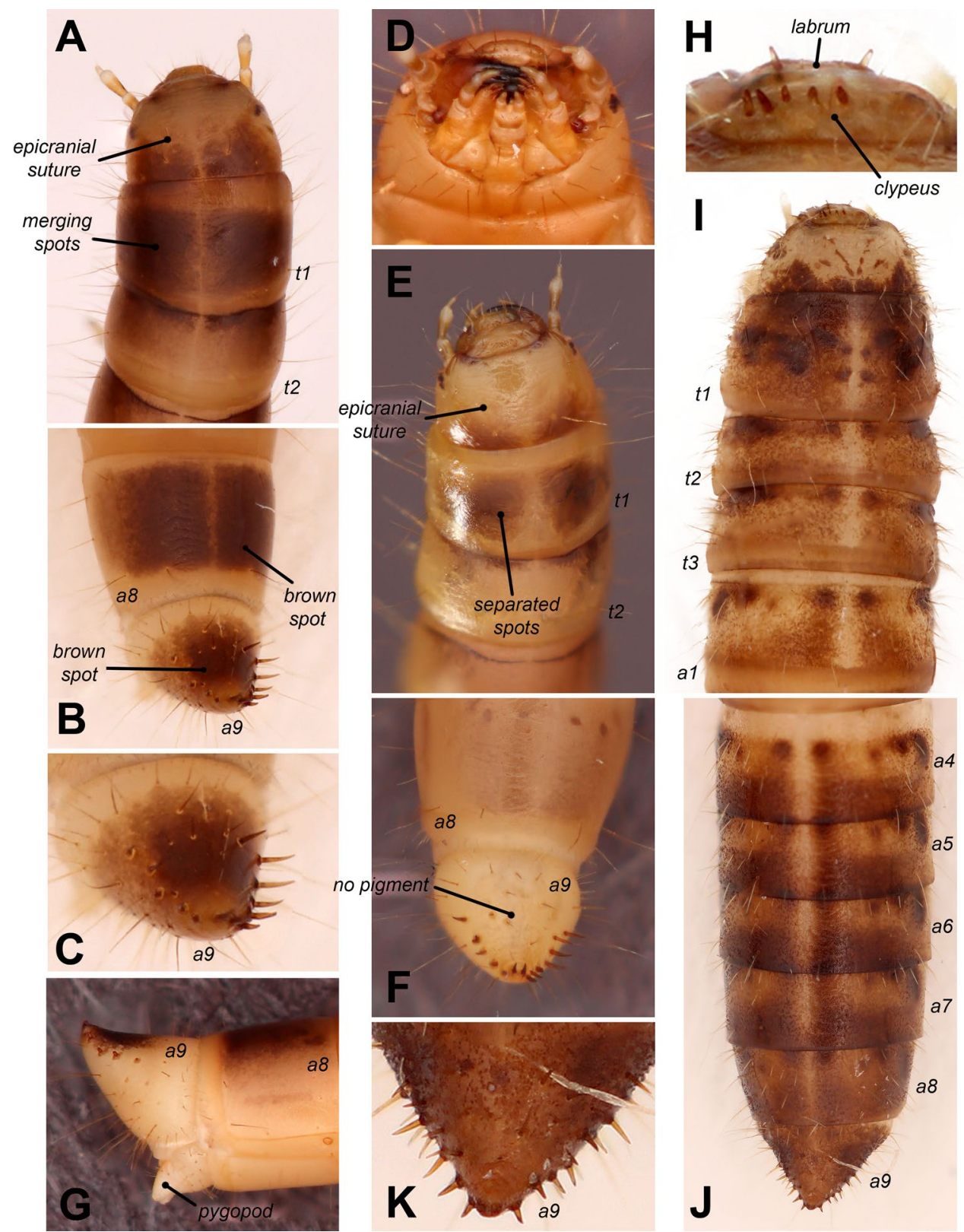

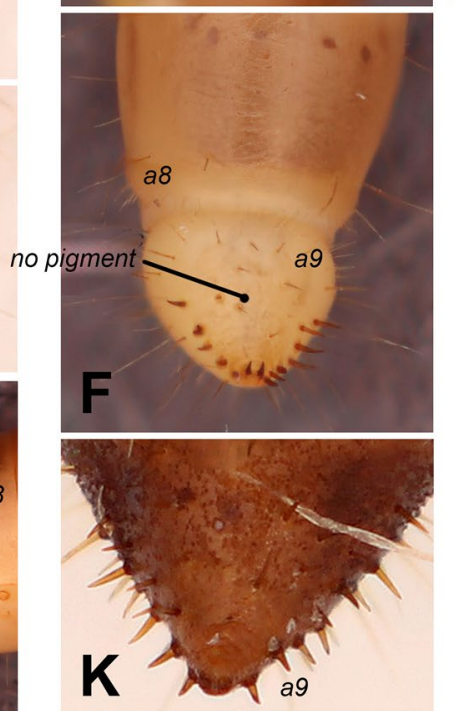

accession numbers: MK714045, MK714058, MK714065 (larva), MK714044, MK714057, MK714064 (imago).

Differential diagnosis Larvae of Blapstinus longulus can be easily separated from those of B. histricus by different color patterns of the dorsal surface of the body, i.e., head with two separate brown spots constricted to dorso-median parts of the epicranial plates (head with a single large spot covering epicranial plates and basal part of frons in B. histricus) (Fig. 5a, e); prothoracic tergum with two separate brown spots on the sides (the whole dorsal surface covered by the spot in B. histricus) (Fig. 5a, e); pygidium without a brown spot on the ventral side (spot present in B. histricus) 
foramen; yellow, with two brown spots each in center of epicranial plates (Fig. 5e); punctation absent or extremely fine. Epicranial suture stem length approximately one-third head capsule length; frontal arms sinuate, extend to antennal insertion. Frons faintly rugose, with microsculpture. Epicranial plates weakly rugose dorsally, with microsculpture; each plate with deep setose area in middle; lateral portions moderately setose (11-13 setae present); ventral portion of each plate with row of two to three long setae along anterior margin near buccal cavity, not confluent with setae on lateral portions of plates. Two stemmata present on each epicranial plate, pigmented and well visible. Clypeus trapezoidal, slightly darker medially, with four deep setose areas of which two are located medially and others laterally. Labrum transverse, weakly emarginate, without noticeable setation. Epipharynx anterolateral margins with six spinose setae; four subanterior sensory papillae present, arranged as transverse row subtended by two spinose setae. Mandibles asymmetrical, their bifid apices strongly sclerotised and dark; left mandible with triangular premolar tooth and two distinct apical teeth; right mola reduced, with single apical tooth. Labium with distinct prementum, mentum and submentum; gula well developed (Fig. 5d), elongate, rectangular; subquadrate prementum bears pair of setae in center, ligula twice shorter, narrower than first labial segment, labial palps 2-segmented; mentum elongated, with pair of setae at base and 2 pairs of longer setae lateromedially; submentum trapezoidal with pair of setae basally. Hypopharyngeal sclerome pentagonal; tricuspidate, with apical denticle elongated; with deep depression in middle. Maxillary palpi 3-segmented, first and third segments of same length, second one about 1.2 longer. Antennae 3-segmented, second antennomere is 4.0 times longer than wide and about 1.2 times longer than first.

Thorax Thoracic tergites yellow (Fig. 3c). Prothoracic tergum subquadrate, about $2 \times$ length of meso- or metaterga; with two brown spots laterally (Fig. 5e). Meso- and metathoracic tergites wider than long, apically each with brown band. Thoracic tergites sparsely setose on dorsal surfaces. Lateral margin of protergum with eight to ten long setae in anterior part. Mesothoracic spiracle simple, ovate, approximately $1.5 \times$ size of abdominal spiracles; reduced metathoracic spiracle visible. Legs. Prothoracic leg slightly longer and thicker than meso- and metathoracic legs; prothoracic tarsungulus strongly sclerotized; prothoracic trochanter with two stout spines ventroapically; prothoracic femur and tibia with ventromedial row of two spines. Prothoracic tarsungulus about $0.5 \times$ length of femur and tibia; about $0.7 \times$ length of trochanter. Mesotibia with two ventromedial spines.

Abdomen Abdominal tergites yellow, faintly rugose, with sparse elongate seate laterally. Abdominal sternite I with narrow brown band in apical part. Abdominal laterotergites with lateral margins indistinctly pigmented. Abdominal segment VIII with row of four setae basally and brownish spot in middle. Pygidium triangular and with brown spot in dorsal view (sometimes brown spot is absent-Fig. 5f), gradually upturned to apex, urogomphi absent; marginal row of 12-16 socketed spines present, arranged as single row around posterior two-thirds to one half of segment; basal row of eight soft setae located outside of brown spot (Fig. 5f, g). Pygopods short, subconical (Fig. 5g).

Genus Trichoton Hope, 1841

Type species: Trichoton cayennense Hope, 1841 (by original designation).

=Epilasium Curtis, 1844 syn. by Mulsant and Rey (1853)

Type species: Epilasium rotundatum Curtis, 1844 (by monotypy).

$=$ Bycrea Pascoe, 1868 syn. nov.

Type species: Bycrea villosa Pascoe, 1868 (by monotypy).

Justification for new generic synonymy Comparison of the larval morphology of T. sordidum and Bycrea villosa (see Steiner 2004) revealed that both those species share unique clypeal and labral setation (Fig. 5h) and similar pigmentation of the body segments-especially the head (Fig. 5i). Moreover, newly analysed molecular data suggest a close phylogenetic affiliation of Trichoton and Bycrea. Both genera form a separate clade within Blapstinina (Fig. 2). Analysis of imaginal morphology and available references show Trichoton is only defined by the lack of presumably autapomorphic features of Bycrea (i.e. absence of strongly elongated spine on protibia, weakly developed (not widened) basal protarsomeres, mesotibia without median tooth on the outer side (all three features concern male morphology), protibia not triangular, antennomeres 7-11 not transverse, maxillary palp more triangular). On the other hand, both entities share many key features, i.e. curved protibiae, distinctly bisinuate base of pronotum and triangular scutellum (see Davis 1976), glabrous (not covered with setae) basal fcorners of the fifth abdominal ventrite (presently observed feature, Fig. 1b). According to Aalbu and Triplehorn (1985) both genera can be separated by differing head structure (eyes not fully divided in Bycrea; fully divided into dorsal and ventral portions in Trichoton). However, this statement is false. The eyes of Bycrea villosa are fully divided, just as in all Trichoton and other Blapstinina (for details see Iwan and Kaminski 2016). 
To sum up, all of the analysed data sets (larval and imaginal morphology, molecular data) suggest a close phylogenetic relation between Trichoton and Bycrea. As a result, Bycrea is hereby interpreted as a synonym of Trichoton. In the light of gathered data, Bycrea could not be interpreted as a separate genus-group taxon close to Trichoton because of the lack of morphological synapomorphies supporting monophyly of Trichoton in such a phylogenetic scenario. The apomorphic morphology of Trichoton villosum comb. nov. is likely due to this species' myrmecophilous affiliation(s) (Rojas 1988).

Label data of the studied adult Trichoton specimens used for reference are presented in Electronic Supplementary Material Appendix 1.

Note In 2001, Ferrer \& Moraguès introduced Marcuzzichoton as a new subgenus of Trichoton. However, the authors did not designate a type species for the new genus-group name, as required by Articles 13.3 and 67.4.1 of the ICZN (1999), and therefore the new name was considered unavailable. After this mistake was pointed out, the same authors published a short paper to rectify the situation (Ferrer and Moragues 2002). In this second paper, they selected Opatrum occidentale Berg as the type species of the new genus-group name they proposed in 2001. However, a subsequent designation of a type species is not allowed by the ICZN (1999) for the generic names proposed after 1930. Therefore this action did not make Marcuzzichoton available. Furthermore, by referring to "Marcuzzichoton Ferrer \& Moraguès, 2001" in their second paper, they failed to fulfil Article 16.1 of the the ICZN (1999). As a result, Marcuzzichoton Ferrer and Moraguès is unavailable in both of their papers.

\section{Trichoton sordidum (LeConte, 1851)}

Material examined Larvae were reared from adults with the following collecting information: "Boulder Recreation Area, Maricopa County, Arizona Nov. 23rd 2017". A total of three larvae were reared. However, two of them represent earlier instar larvae. Therefore, the following description was made based on a single, not dissected, specimen. GenBank accession numbers: MK714048, MK714061, MK714068 (imago).

Differential diagnosis Larvae of Trichoton sordidum can be easily separated from those of the above described Blapstinus species by the differing setation of clypeus (row of eight spinose setae on anterior margin of clypeus; lack of spinose setae in both Blapstinus species), labrum (row of four spinose setae on anterior margin of labrum in $T$. sordidum; lack of spinose setae in both Blapstinus species), mandibles (pair of spinose setae present laterally on apical part in T. sordidum; lack of spinose setae in both Blapstinus species) and pygidium (24 spinose setae irregularly arranged on margin in T. sordidum; 12-16 spinose spines arranged as single row around posterior two-thirds to one half of pygidium in both Blapstinus species) (Fig. 5c, f, k). Moreover, the larvae of $T$. sordidum are also characterised by having prothoracic tibia with ventromedial row of three spines (two spines in both Blapstinus species). The clypeal and labral setation of Trichoton villosum comb. nov. is similar to that observed for Trichoton sordidum (see above). Both Trichoton species can be easily told apart by differing spot patterns of the abdominal terga (segments IV-VII with brownish bands in the apex in T. sordidum; without brownish bands in T. villosum (see Steiner 2004).

Description TL: $8.5 \mathrm{~mm}$, HW: $1.0 \mathrm{~mm}$, PL: $1.0 \mathrm{~mm}$, PW: $1.5 \mathrm{~mm}, \mathrm{PL} / \mathrm{mesothoracic}$ length $=2.0 ; \mathrm{PL} / \mathrm{mesothoracic}$ length $=1.3$.

Head Prognathous, distinctly retracted into prothorax; weakly dorsoventrally flattened; narrower than prothorax; sides rounded; strongly constricted before occipital foramen; yellow, single brown spot covering epicranial plates and two narrow brown bands directed anteriorly (visible on frons) (Fig. 5i); punctation absent or extremely fine. Epicranial suture stem length approximately one-third head capsule length; frontal arms sinuate, extend to antennal insertion. Frons faintly rugose, with microsculpture. Epicranial plates weakly rugose dorsally, with microsculpture; each plate with deep setose area in middle; dorsal and lateral portions densely setose; ventral portion of each plate with row of four long setae along anterior margin near buccal cavity, not confluent with setae on lateral portions of plates. Two stemmata present on each epicranial plate, pigmented and well visible. Clypeus trapezoidal, yellow without darker spots, with row of eight spinose setae in apical portion. Labrum transverse, weakly emarginate, with apical row of four spinose setae (Fig. 5h). Epipharynx not dissected. Mandibles asymmetrical; pair of spinose setae present laterally on apical part. Labium with distinct prementum, mentum and submentum; gula well developed, elongated and rectangular; subquadrate prementum bears pair of setae in center, ligula half as long, narrower than first labial segment, labial palps 2-segmented; mentum elongated, with pair of setae at base and 2 pairs of longer setae lateromedially; submentum trapezoidal with pair of setae basally. Hypopharyngeal sclerome not dissected. Maxillary palpi 3-segmented, first and third segments of same length, second one about 1.2 longer. Antennae 3-segmented, second antennomere is 2.0 times longer than wide and about 2 times longer than first. 
Fig. 6 Larval morphology of Eurynotus rudebecki: a, b head in dorsal view, c mouthparts in ventral view, $\mathbf{d}$ close-up of ligula, e hypopharyngeal sclerome, $\mathbf{f}$ epipharynx, $\mathbf{g}$ front leg, $\mathbf{h}$ mesothorax in ventral view, $\mathbf{i}$ pygidium

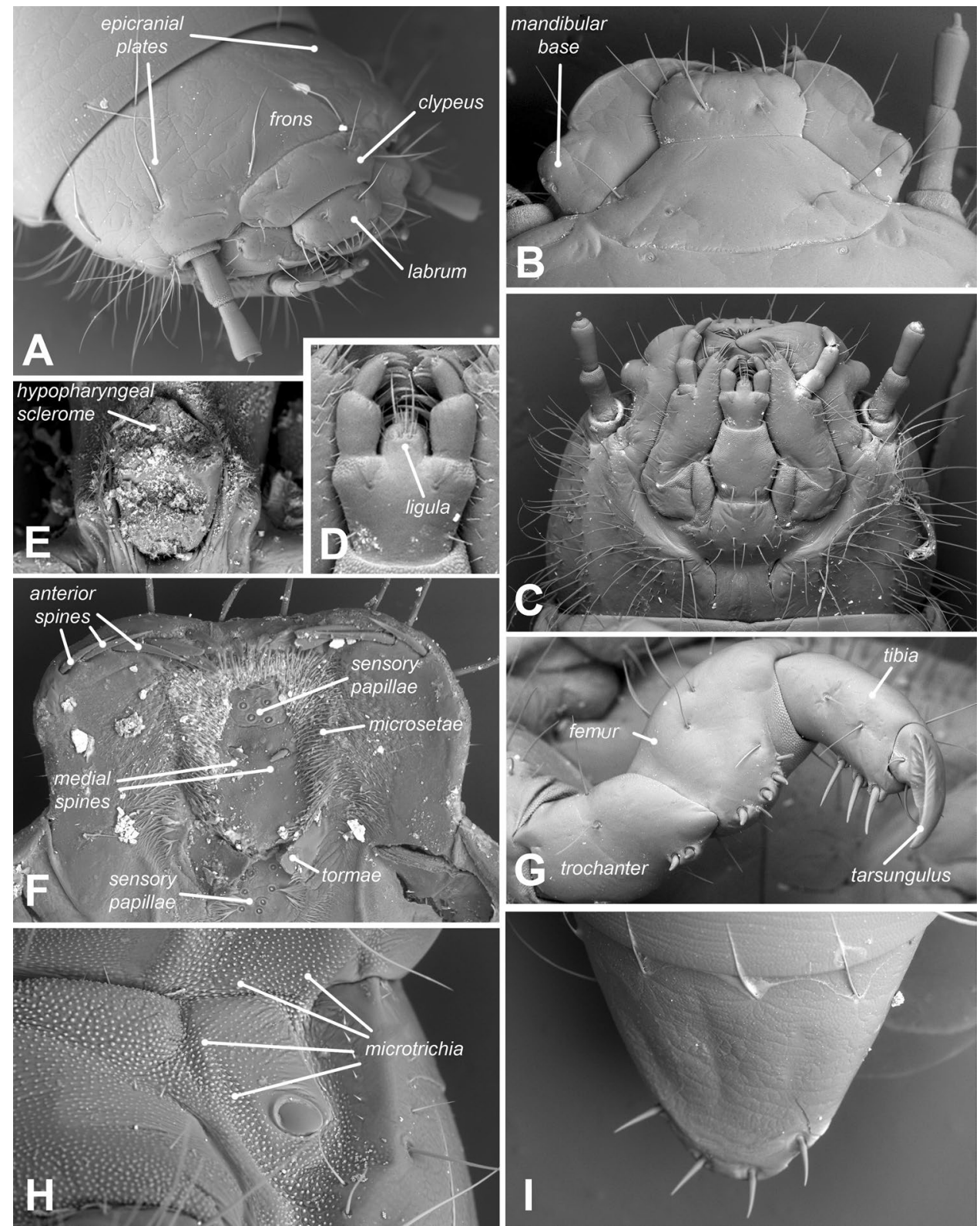

Thorax Thoracic tergites yellow, but covered with brownish spots (in some cases confluent) (Figs. 3d,5i). Prothoracic tergum transverse, about $2 \times$ length of mesoterga and $1.5 \times$ length of metaterga. Brown spots of thoracic segments interrupted medially (Fig. 5i). Thoracic tergites denselly setose on dorsal and lateral surfaces. Mesothoracic spiracle simple, ovate, approximately $1.5 \times$ size of abdominal spiracles; metathoracic spiracle not visible. Legs. Prothoracic leg slightly longer, thicker than mesoand metathoracic legs; prothoracic tarsungulus strongly sclerotized; prothoracic trochanter with two stout spines ventroapically; prothoracic femur with ventromedial row of two spines; prothoracic tibia with ventromedial row of three spines. Prothoracic tarsungulus about 0.7 length of trochanter, femur and tibia. Mesotibia with two ventromedial spines.

Abdomen Abdominal tergites covered with brownish spots, especially noticeable on segments IV-VIII (Fig. 5j) and covered with long and dense setae. Pygidium triangular and with wide brown band, suddenly upturned to apex, urogomphi absent; marginal row of 24 socketed spines present, not arranged as single row; basal row of eight soft setae located outside of brown spot (Fig. 5j, k). Pygopods short, subconical. 


\section{PLATYNOTINI: Eurynotina}

Genus Eurynotus Kirby, 1819

Eurynotus rudebecki Koch, 1955

Material examined Larvae were reared from adults with the following collecting information: "Mossel Bay, South Africa, -34.147305, 22.065792, 9.1.2017, leg. M.J. Kamiński \& A.D. Smith". A total of 48 larvae were reared and examined for this study. Selected specimens were preserved at the entomological collection of the Museum and Institute of Zoology, Polish Academy of Sciences. GenBank accession numbers: MK714050, MK714053, MK714070 (larva), MK714049, MK714052, MK714069 (imago).

Differential diagnosis See discussion under Platynotini.

Description TL: $29.0-32.0 \mathrm{~mm}$, HW: $2.1-2.2 \mathrm{~mm}$, PL: 1.9$2.2 \mathrm{~mm}$, PW: $2.4-2.7 \mathrm{~mm}$, PL/mesothoracic length $=1.5-$ 2.5; PL/mesothoracic length $=1.2-1.4$.

Head Prognathous, distinctly retracted into prothorax; head capsule weakly dorsoventrally flattened; slightly narrower than prothorax (in earlier stages $\mathrm{HW}=\mathrm{PW}$ ); sides rounded; strongly constricted before occipital foramen; color dark brown, same as body segments (Fig. 3e); punctation absent. Epicranial suture stem length approximately one-third head capsule length; frontal arms sinuate, double branched apically, not reaching epistomal margin (Fig. 6a). Frons faintly rugose, with visible microsculpture, with pair of deep setose points at apex (Fig. 6a). Epicranial plates weakly rugose dorsally, with microsculpture; each plate with deep setose points in middle and apex (Fig. 6a); lateral and ventral portions densely setose (several long setae present). Five stemmata in two rows (transverse ophthalmic spots) present on each epicranial plate, pigmented and well visible. First row composed on three separated ocelli situated just before epicranial margin near antennal insertion; second row with two partly fused stemmata. Clypeus trapezoidal, with four deep setose points of which two are located medially while remaining two laterally (Fig. 6b). Labrum transverse, weakly emarginate, basally with pair of long setae, apical margin with row of eight setae. Epipharynx as on Fig. $6 \mathrm{f}$. Mandibles asymmetrical, apical tooth of right mandible well developed, covering apical part of the tooth of left mandible, their bifid apices and molar part strongly sclerotised and dark; outer margin roundly extended outwards (visible from dorsal view), with distinct emargination in middle of the outer ridge (Fig. 6b). Labium with distinct prementum, mentum and submentum; gula apically well developed (Fig. 6c), elongated and trapezoidal; subquadrate prementum, setation variable, ligula of same width as first labial segment (Fig. 6d), labial palps 2-segmented; mentum elongated, hexagonal, with elongated setae distributal at base and sides; trapezoidal submentum with irregular setation. Hypopharyngeal sclerome pentagonal; tricuspidate, with apical denticle slightly elongated (Fig. 6e). Maxillary palpi 3-segmented, first and third segments of same length, second one about 1.2 longer. Antennae 3-segmented, second antennomere is 2.0 times longer than wide, same length as first one (Fig. 6c).

Thorax Thoracic tergites dark brown (Fig. 3e). Prothoracic tergum subquadrate, about $2 \times$ length of meso- and $1.4 \times$ metaterga. Meso- and metathoracic tergites wider than long). Thoracic tergites sparsely setose on dorsal surfaces. Mesothoracic spiracle simple, ovate (ca. $2.4 \times$ as long as wide) (Fig. 6h), approximately $1.5 \times$ size of abdominal spiracles; reduced metathoracic spiracle visible. Thoracic sternites densely covered by microtrichia (Fig. 6h). Legs. Prothoracic leg noticeably longer, much thicker than meso- and metathoracic legs; prothoracic tarsungulus strongly sclerotized, with visible suture at base on ventral side; prothoracic trochanter with two stout spines ventroapically; prothoracic femur with ventromedial row of four spines; prothoracic tibia with ventromedial row of two or three spines (Fig. 6g). Prothoracic tarsungulus about $0.8 \times$ length of tibia; same length as trochanter. Mesotibia with two ventromedial spines.

Abdomen Abdominal tergites dark brown, faintly rugose, with sparse elongate seate laterally. Abdominal sternite I with patch of setae basally. Pygidium triangular, distinctly narrowing apically, urogomphi absent; marginal row of four socketed spines present at 6/7 length from base (in earlier stages pygidium more ovate at apex, spines located at 4/5 length from base), arranged as single row around posterior edge (distance between spines equals spine length); basal row composed of four soft setae (Fig. 6i). Pygopods short, subconical.

\section{Discussion}

Larval morphology has been proven to be an important data source for inferring phylogenetic relations among major groups of darkling beetles (Skopin 1962, 1964; Watt 1974). Because of their different lifestyles, adults and immature stages have separate evolutionary histories (Corbet 1962; Matthews et al. 2010). Theoretically, this should enable cross-testing of phylogenetic hypotheses obtained based on adult and immature data. However, in most cases, it is unclear how specific selective pressures acting on the larval 
Table 2 Selected, non-exhaustive list of species of Opatrines and their hosts with associated publication(s)

\begin{tabular}{|c|c|c|c|}
\hline Taxon & Crop & Country & Sources \\
\hline \multicolumn{4}{|l|}{ DENDARINI } \\
\hline \multicolumn{4}{|l|}{ I. Dendarina } \\
\hline $\begin{array}{l}\text { Dendarus crenulatus (Ménétriés, } \\
\text { 1832) }\end{array}$ & Melon, seeds of different crops & Azerbaijan & Medvedev (1968) \\
\hline $\begin{array}{l}\text { Dendarus foraminosus Mulsant \& } \\
\text { Rey, } 1855\end{array}$ & Grapevines & Ukraine & Medvedev (1968) \\
\hline Phylan gibbus (Fabricius, 1775) & Pines & Europe & Medvedev (1968) \\
\hline \multicolumn{4}{|l|}{ II. Melambiina } \\
\hline Allophylax picipes (Oliver,1811) & Cotton, tobacco & Malta & Medvedev (1968) \\
\hline \multicolumn{4}{|l|}{ OPATRINI } \\
\hline \multicolumn{4}{|l|}{ I. Blapstinina } \\
\hline Blapstinus brevicollis LeConte, 1851 & $\begin{array}{l}\text { Sugar beets, horseradish, grapes, dried } \\
\text { fruits }\end{array}$ & USA & Allen (1937) \\
\hline Blapstinus dilatatus LeConte, 1851 & Bell pepper & USA & Allen (1937), Elmore (1948) \\
\hline Blapstinis discolor Horn, 1870 & Plant species-not specified & USA & Elmore (1948) \\
\hline Blapstinus histricus Casey, 1890 & Bell pepper & USA & Allen 1937, Elmore (1948) \\
\hline $\begin{array}{l}\text { Blapstinus metallicus (Fabricius, } \\
\text { 1801) }\end{array}$ & Tobacco & USA & Allen 1937 \\
\hline Blapstinus pimalis Casey, 1885 & Cotton & USA & Allen 1937, Elmore (1948) \\
\hline $\begin{array}{l}\text { Blapstinus substriatus Champion, } \\
1885\end{array}$ & $\begin{array}{l}\text { Beets, flax, mustard, winter wheat, and } \\
\text { 'garden crops' }\end{array}$ & USA & Allen (1937) \\
\hline Blapstinus sulcatus LeConte, 1851 & Stored grain & USA & Papp and Pierce (1960) \\
\hline Ulus crassus (LeConte 1851) & $\begin{array}{l}\text { Guayule (Parthenium argentatum), lima } \\
\text { bean, stored grain }\end{array}$ & USA & Elmore (1948), Papp and Pierce (1960) \\
\hline Ulus elongatulus Casey, 1890 & Cabbage & USA & Steiner (2003) \\
\hline Ulus hirsutus Champion, 1885 & Corn and sunflower & USA & Steiner (2003) \\
\hline \multicolumn{4}{|l|}{ Not fully identified records: } \\
\hline Blapstinus sp. & Cantaloupe, cotton & USA & Roberts (1947) \\
\hline Blapstinus sp. & Lepidium virginicum $\mathrm{L}$. & USA & Strauss et al. (2002) \\
\hline Blapstinus sp. & Lima bean & USA & Elmore (1948) \\
\hline Blapstinus spp. & Melons & USA & LeBoeuf (2002) \\
\hline Blapstinus spp. & Peanuts & USA & Chittenden and Marsh (1910) \\
\hline Blapstinus spp. & Strawberries & USA & Wilcox and Howland (1943) \\
\hline \multicolumn{4}{|l|}{ II. Opatrina } \\
\hline $\begin{array}{l}\text { Gonocephalum amplithorax (Fair- } \\
\text { maire, 1894) }\end{array}$ & $\begin{array}{l}\text { Barley, bean, chick pea, coffee, cotton, } \\
\text { corn, groundnut, lupin, pyrethrum, } \\
\text { rice, sorghum, sugarcane, sunflower, } \\
\text { tobacco, tomato, wheat (Triticum } \\
\text { aestivum L.) }\end{array}$ & Zimbabwe & Medvedev (1968), Drinkwater (1999) \\
\hline $\begin{array}{l}\text { Gonocephalum bimaculatum Ferrer, } \\
1995\end{array}$ & Lucerne, wheat & South Africa & Drinkwater (1999) \\
\hline $\begin{array}{l}\text { Gonocephalum carpentariae (Black- } \\
\text { burn, 1894) }\end{array}$ & Sugar cane & Australia & Medvedev (1968) \\
\hline $\begin{array}{l}\text { Gonocephalum coenosum Kaszab, } \\
1952\end{array}$ & Coffee, sugar cane, tobacco & Java, Philippines & Medvedev (1968) \\
\hline $\begin{array}{l}\text { Gonocephalum elderi (Blackburn, } \\
\text { 1892) }\end{array}$ & Cereals/grains & South Africa & \\
\hline Gonocephalum gridellii Koch, 1953 & Corn, sorghum, and sunflower & South Africa & Drinkwater (1999) \\
\hline $\begin{array}{l}\text { Gonocephalum hoffmannseggi (Ste- } \\
\text { ven, 1829) }\end{array}$ & Tobacco & India & Medvedev (1968) \\
\hline $\begin{array}{l}\text { Gonocephalum macleayi Blackburn, } \\
1907\end{array}$ & Bread cereal & Australia & Medvedev (1968) \\
\hline
\end{tabular}


Table 2 (continued)

\begin{tabular}{|c|c|c|c|}
\hline Taxon & Crop & Country & Sources \\
\hline $\begin{array}{l}\text { Gonocephalum pusillum (Fabricius, } \\
\text { 1791) }\end{array}$ & $\begin{array}{l}\text { Anise, barley, beet, cabbage, castor, } \\
\text { corn, cotton, dill, fennel, sorghum, } \\
\text { sunflower, tobacco, tomato }\end{array}$ & Eurasia & Medvedev (1968) \\
\hline $\begin{array}{l}\text { Gonocephalum reticulatum Mots- } \\
\text { chulsky, } 1854\end{array}$ & Cabbage, sugar cane & $\begin{array}{l}\text { Korea, Mongolia, } \\
\text { Turkmenistan }\end{array}$ & Reichardt (1936), Medvedev (1968) \\
\hline $\begin{array}{l}\text { Gonocephalum rusticum (Olivier, } \\
\text { 1811) }\end{array}$ & Cotton, watermelon & Uzbekistan & Reichardt (1936), Medvedev (1968) \\
\hline $\begin{array}{l}\text { Gonocephalum sentulosum (Lind- } \\
\text { berg, 1950) }\end{array}$ & Different plant species - not specified & Tajikistan & Medvedev (1968) \\
\hline $\begin{array}{l}\text { Gonocephalum seriatum (Boisduval, } \\
\text { 1835) }\end{array}$ & Pineapple & Hawaii & Medvedev (1968) \\
\hline Opatroides curtulus Fairmaire, 1892 & Grapevines, tobacco & & \\
\hline Opatroides frater (Fairmaire, 1896) & Tobacco & India & Medvedev (1968) \\
\hline Opatroides punculatus Brullé, 1832 & $\begin{array}{l}\text { Cereals, cotton, grapevines, melon, } \\
\text { pumpkin, tobacco }\end{array}$ & Eurasia & Medvedev (1968) \\
\hline Opatrum libani Baudi di Selve, 1876 & Fruit trees, grapevines, tobacco & Palestine & Reichardt (1936) \\
\hline Opatrum perlatum Germar, 1824 & Grapevines (roots) & Palestine & Reichardt (1936) \\
\hline $\begin{array}{l}\text { Opatrum sabulosum (Linnaeus, } \\
1760 \text { ) }\end{array}$ & $\begin{array}{l}\text { Barley, bean, beet, chick pea, cotton, } \\
\text { corn, cucumber, flax, fennel, hemp, } \\
\text { lallemantia, lens, melons, millets, } \\
\text { mushroom, mustard, oats, onion, } \\
\text { perilla, poppy, potato, rape, safflower, } \\
\text { sage, sorghum, Sudan grass, sunflower, } \\
\text { tomato, tobacco, wheat, winter cress }\end{array}$ & Transcaucasia & $\begin{array}{l}\text { Medvedev (1968), Cherney and } \\
\text { Fedorenko (2006) }\end{array}$ \\
\hline Opatrum triste (Steven, 1829) & $\begin{array}{l}\text { Clary, guizotia, oil crops, sesame, } \\
\text { tobacco, vine grapes }\end{array}$ & Ukraine & Medvedev (1968) \\
\hline $\begin{array}{l}\text { Penthicus dilectans (Faldermann, } \\
\text { 1836) }\end{array}$ & Cotton & Eurasia & Medvedev (1968) \\
\hline \multicolumn{4}{|l|}{ PEDININI } \\
\hline \multicolumn{4}{|l|}{ I. Leichenina } \\
\hline $\begin{array}{l}\text { Leichenum canaliculatum (Klug, } \\
\text { 1833) }\end{array}$ & $\begin{array}{l}\text { Bermuda grass, cotton, damaged peach } \\
\text { trees and Amaryllis bulbs, turnips, } \\
\text { rutabagas, rugs }\end{array}$ & USA & St. George (1930), Spilman (1959) \\
\hline \multicolumn{4}{|l|}{ II. Pedinina } \\
\hline Pedinus femoralis (Linnaeus, 1767) & $\begin{array}{l}\text { Ambary, barley, beet, castor, clover, } \\
\text { corn, cotton, cucumber, fennel, flax, } \\
\text { hemp, lucene, melon, potato, safflower, } \\
\text { soya, sunflower, tobacco, tomatoes, } \\
\text { wheat }\end{array}$ & Eurasia & $\begin{array}{l}\text { Medvedev (1968), Cherney and } \\
\text { Fedorenko (2006) }\end{array}$ \\
\hline Pedinus strabonis Seidlitz, 1893 & Dry seeds & Transcaucasia & Medvedev (1968) \\
\hline $\begin{array}{l}\text { Pedinus strigicollis strigosus (Costa, } \\
\text { 1847) }\end{array}$ & Tobacco roots & Ukraine & Medvedev (1968) \\
\hline \multicolumn{4}{|l|}{ PLATYNOTINI } \\
\hline \multicolumn{4}{|l|}{ I. Platynotina } \\
\hline Anomalipus sp. & Tobacco & Zimbabwe & Jack (1917) \\
\hline
\end{tabular}

stage might influence their usefulness for phylogenetic studies. In the case of opatrinoid beetles, it was proven that at least part of the currently known morphological variability was derived from ecological factors, especially in desert living (Schulze 1969) or myrmecophilous taxa (see Trichoton). This is likely the main reason why despite having a relatively comprehensive coverage of larval descriptions across the known subtribal diversity (Table 1), no features concerning immature stages were able to be used to define any family-group taxa within the 'Opatrinoid' clade (Iwan and Kamiński 2016; Kamiński et al. 2019). The present study revealed a great variability of larval morphology among the major opatrinoid subclades recovered by Kamiński et al. (2019). However, larval features seem to be extremely informative at the generic level in some cases (see below). 
Further descriptive studies should focus primarily on representatives of unstudied genera and species with outstanding ecology (e.g., ultrapsammophilous taxa). In addition, further larval descriptions may also have utilitarian uses, as larvae of many species representing the 'Opatrinoid' clade are common pests (Table 2).

Dendarini. The description presented here for Zadenos mulsanti is the first comprehensive contribution to our knowledge of larval morphology within Melambiina. The other available publications are rather accidental (Table 1); thus, only general conclusions can be made here.

Both representatives of Melambiina share the same setation pattern of pygidium, i.e., four distinct spines present on the anterior edge (Fig. 4g). This feature is also shared by Dendarus punctatus from Dendarina (Medvedev 1968; Skopin 1978; Cherney 2005). However, it cannot be treated as a common feature of all Dendarini since other known larvae (i.e., Heliopates and Phylan) possess eight spines instead of four (Skopin 1978). According to the phylogeny presented by Kamiński et al. (2019), Heliopates is paraphyletic in relation with Phylan. Therefore, the above-mentioned spine arrangement might be diagnostic for the Heliopates + Phylan clade. However, more descriptions are required to fully test this hypothesis.

Larvae of Z. mulsanti can be easily distinguished from those of $D$. punctatus by the different arrangement of spines on front legs (Fig. 2a). In Zadenos, the trochanter and femur are each equipped with a pair of spines, while there are three spines are present on the tibia (Fig. 4e). Contrarily, in Dendarus, the following pattern is observed: trochanter with four spines, femur with six, and tibia with two (Cherney 2005). The other available descriptions concerning Dendarini are incomplete or ambiguous, preventing further comparisons.

Opatrini. The analysed material revealed a great level of morphological variability within the studied Blapstinina larvae (Fig. 5). At this point, it is impossible to propose any diagnostic characters concerning this developmental stage which define the subtribe. However, it can be noted that the front legs of Blapstinina larvae are only slightly enlarged in relation with other known cases representing the Opatrinoid clade, with the exception of Stizopina (Schulze 1963). On the other hand, the larval morphology proved to be extremely informative at the generic level (see above under Trichoton).

A similar pattern was revealed for the most intensively studied subtribes of Opatrini [i.e., Opatrina and Stizopina (Table 1)]. For example, the spine pattern of the edge of pygidium varies significantly in Opatrina (eight spines arranged on a single row in some Penthicinus species; up to 22 in Melanestes; 20 distributed on margins in middle of pygidium in Scleropatrum) (Dai et al. 2000; Jia et al. 2014; Jinxia and Youzhi 2000; Li et al. 2013; Ren et al. 2000; Yu et al. 2000a, b, c; Yu and Ren 1994a, b, Zhang and Yu 2004; Cherney 2005). In Stizopina, this variability is even greater (Fig. 2). The strongest modifications within this subtribe were observed for the highly specialised, psammophilous genera, such as Psammogaster. In this case, no apical spines on pygidium are present, while the other known taxa have up to 18 spines (in different arrangements) (Schulze 1963). On the other hand, all known Stizopina larvae do not have ocelli, which seems to be unique across the 'Opatrinoid' clade (Schulze 1963).

An additional observation of interest is that despite the high variability in pygidium morphology, no Opatrini species were reported to possess four distinct apical spinesa commonly observed feature within other closely related tribes (Figs. 4g,6i). This also holds true for Amphidorini (Wade and Boving 1921; Smith et al. 2014), a tribe recovered sister to the 'Opatrinoid' clade (Kamiński et al. 2019).

The available contributions for other subtribes (Ammobiina and Heterotarsina) are extremely fragmentary, with the few represented taxa reflecting little of the diversity of the group(s), inhibiting further analysis (Table 1).

Pedinini. Although no immature stages of this tribe are described here, the comparison of available larval descriptions with the newly introduced phylogenetic context resulted in some interesting conclusions. One of the main problems encountered by Kamiński et al. (2019) concerned the phylogenetic relationship between Helopinina and Leichenina. In one scenario, the latter was recovered sister to all other Pedinini, while in the second, it was nested within Helopinina (sister to the genus Drosochrus). Based on adult morphology, Kamiński et al. (2019) favored the first solution. As a result, the three following subtribes were designated: Helopinina, Leichenina, and Pedinina. The larval descriptions for all those entities presently exist (Table 1).

Comparative analysis revealed that Helopinina is the most variable subtribe in terms of larval morphology. It is best visualised in the modifications of the setation arrangement of the pygidium (Schulze 1968). Contrary to Leichenina and Pedinina, no known Helopinina larvae possess four apical spines (Schulze 1969). Moreover, the larvae of Leichenum are clearly characterised by a unique, within Pedinini, structure of the clypeus and labrum (St. George 1930; Cherney 2005; Dunford and Steiner 2007). In conclusion, no larval features directly linking Helopinina and Leichenina were found during the present study. This supports the classification concept proposed by Kaminski et al. (2019). For detailed analysis of the larval morphology within Helopinina, see Schulze (1968).

Finally, the setation of larval forelegs seems to be relatively stable within Pedinini. The majority of known species 
are characterised by having a pair of spines on each of the following segments: trochanter, femur, and tibia (St. George 1930, Keleinikova 1966; Medvedev 1968; Schulze 1968; Cherney 2005; Dunford and Steiner 2007). The only known exceptions concern a few species of Micrantereus species, which posses a single spine on the protibia (Schulze 1968). This spine arrangement (2-2-2) is not shared by the most closely related tribes, i.e., Dendarini and Platynotini (e.g., Figs. 4e,6g). However, it was observed within several species representing Opatrini (Dai et al. 2000; Jia et al. 2014; Jinxia and Youzhi 2000; Li et al. 2013; Ren et al. 2000; Yu et al. 2000a, b, c; Yu and Ren 1994a, b; Zhang and Yu 2004, Cherney 2005).

Platynotini. Because Schulze (1969) did not attach any descriptions for the Heteropsectropus larva illustrated in her paper, and Tschinkel's (1978) contribution concerned the first instar larvae, this paper is first to provide data which can be used for comparative studies on higher phylogenetic levels. The available reference knowledge on Platynotina is presented by Iwan (1995), Iwan and Bečvář (2000) and Iwan and Schimrosczyk (2008).

The morphology of E. rudebecki larvae is highly consistent with that of the platynotoid and trigonopoid Platynotina (for definitions, see Iwan 2002, and Kamiński 2015), i.e., Alaetrinus, Anchophthalmus, Bantodemus, Glyptopteryx, Opatrinus, and Zophodes (Table 1). This seems to also hold true for the undescribed larvae of Heteropsectropus (Schulze 1969); however, the material concerning this species was not realised here. The above-mentioned affiliation is supported by the following features: clypeus with two pairs of setae (Fig. 6a, b), labrum with a median pair of setae and eight apical setae (Fig. 6a, b), and pygidium with four apical spines (Fig. 6i). However, these characteristics are likely plesiomorphic for the Dendarini + Pedinini + Platynotini clade, as they were also recovered in Pedinina and Melambiina (Fig. 4a). It was also observed by Schulze (1969) that larvae of platynotoid Platynotina resemble those of Scaurini to an astonishing extent.

The larval morphology of other Platynotina lineages is extremely variable (Schulze 1962, 1964, 1978; Iwan and Bečvár 2000). No key features seem to be shared with the presently described larvae of E. rudebecki. However, this species can be easily distinguished from the other known Platynotini larvae by having lateral extensions of mandibles (Fig. 6b).

Economic importance. The number of species with currently known larvae within the 'Opatrinoid' clade is surprisingly low, especially when economic factors are taken into account. A brief literature search performed here indicates that larvae representing this group have been noted as pests of various plant species. The 'Opatrinoid' clade is represented globally, with infestations reported across several tribes and subtribes from such distant countries as Australia, Turkmenistan, The United States of America, and Zimbabwe (Table 2). On the other hand, several tenebrionid species (including representatives of 'Opatrinoid' clade) were observed to feed on common weed species (Ogloblin and Kolobova 1927), i.e., Chenopodium album L., Convolvulus arvensis L., or Polygonum aviculare L. As these insects are cosmopolitan in distribution and impact a wide array of crops, greater research effort into their larval stages (rearing, descriptions, life history, etc.) is needed and warranted to curb negative and potentially enhance positive effects of their presence.

Acknowledgements The authors would like to thank Caixia Yuan (Yan'an University) for sharing some of the important references used in this study and Magdalena Kowalewska for the SEM photographs. The authors are grateful to Patrice Bouchard (Canada) for providing useful nomenclatural information.

Funding This research was supported by a Museum and Institute of Zoology (PAS) grant for young researchers (GWIAZDA 2017) and the NSF ARTS Program (DEB \#1754630).

\section{Compliance with ethical standards}

Conflict of interest The authors declare that they have no conflict of interest.

Human and animal rights We neither used endangered species nor were the investigated animals collected in protected areas. All applicable international, national, and/or institutional guidelines for the care and use of animals were followed.

Informed consent Informed consent was obtained from all individual participants included in the study.

Open Access This article is distributed under the terms of the Creative Commons Attribution 4.0 International License (http://creativeco mmons.org/licenses/by/4.0/), which permits unrestricted use, distribution, and reproduction in any medium, provided you give appropriate credit to the original author(s) and the source, provide a link to the Creative Commons license, and indicate if changes were made.

\section{References}

Aalbu RL, Triplehorn CA (1985) Redefinition of the opatrine tribes in North America with notes on some apterous genera (Coleoptera: Tenebrionidae: Tenebrioninae). Coleopt Bull 39:272-280

Allen GM (1937) Blapstinus substriatus Champion, a sporadic wheat pest in Montana. J Econ Entomol 30:670-675

Arnett RH, Thomas MC (2002) American beetles, vol 2. CRC Press, Boca Raton

Beutel RG, Maddison DR, Haas A (1999) Phylogenetic analysis of Myxophaga (Coleoptera) using larval characters. Syst Entomol 24:171-192

Blanchard E (1845) Histoire des Insectes, traitant de leur moeurs et de leur métamorphoses en générale et comprenant une nouvelle 
classification fondée sur leur rapports naturelles. In: Traité Complet d'Histoire Naturelle. Histoires des Insectes. Tome II. Paris: Firmin Didot Frères

Bouchard P, Löbl I, Merkl O (2007) Nomenclatural notes on tenebrionid beetles of the Palaearctic region (Insecta, Coleoptera). Ann Zool 57:385-394

Brullé GA (1832) In: Bory de Saint-Vincent JBGM (ed) Expédition scientifique de Morée. Section des sciences physiques. Tome III.-1.re partie. Zoologie. Deuxième section.-Des animaux articulés. F.G. Levrault, Paris, [1]+400 + [2 (errata)], pp 1-240

Byzova JB, Kelejnikova SI (1964) Semejstvo Tenebrionidae-Chernotelki [The family Tenebrionidae-darkling beetles]. In: Giljarov MS (ed) Opredelitel' Obitajushhih v Pochve Lichinok Nasekomyh [The Identification Keys of Soil Dwelling Insect Larvae]. Nauka, Moskow, pp 463-496 [in Russian]

Cherney LS (2005) Darkling-beetles (Coleoptera, Tenebrionidae). Fauna of Ukraine. Vol. 19. Beetles. Issue 10. Kiev, Naukova Dumka [In Russian]

Cherney LS, Fedorenko VP (2006) Identification keys to the tenebrionid beetles of Ukraine (Coleoptera, Tenebrionidae) (imago, larvae, pupae) [Opredelitel zhukov-chernotelok fauny Ukrainy (imago, lichinki, kukolki)]. "Kolobig", Kiev [in Russian]

Chittenden FH, Marsh HO (1910) Some insects injurious to truck crops: Notes on the cucumber beetles. U.S. Department of Agriculture Bureau of Entomology Bulletin vol 82, pp 72

Corbet PS (1962) A biology of dragonflies. H.F. G. Witherby, London

Curtis J (1844) Descriptions of the insects collected by Capt. P.P. King, R.N., F.R.S., F.L.S. \& c., in the survey of the Straits of Magellan. Ann Mag Nat Hist 14:218-222

Dai J, Yu Y, Ren G (2000) Description of four species larvae of the genus Penthicus Reitter (Coleoptera: Tenebrionidae). J Hebei Univ 20:83-86

Davis JC (1970) Revision of the genus Blapstinus Sturm of America north of Mexico with notes on extralimital species (Coleoptera: Tenebrionidae). Ph.D. Thesis, The Ohio State University

Davis JC (1976) A review of the genus Blapstinus Coleoptera Tenebrionidae. Trans Ky Acad Sci 37:35-40

Desbrochers des Loges J (1902) Faunule des coléoptères de la France et de la Corse: Tenebrionidae (Suite). Le Frelon 11:1-56

Drinkwater TW (1999) Regional distribution of Gonocephalum species (Coleoptera: Tenebrionidae) in maize fields in South Africa. Afr Entomol 7:183-187

Dugès E (1885) Métamorphoses de la Bycrea villosa Pascoe. Annales de la Société Entomologique de Belgique 29:51-55

Dunford J, Steiner WE (2007) Madagascar beetle, Leichenum canaliculatum variegatum (King) (Insecta: Coleoptera: Tenebrionidae). Entomology and Nematology Department, University of Florida, Institute of Food and Agricultural Sciences Extension, EENY399 http://edis.ifas.ufl.edu/pdffiles/IN/IN72300.pdf

Elmore JC (1948) The control of darkling ground beetles. J Econ Entomol 41:988

Eschscholtz JF (1829) Zoologischer Atlas enthaltend Abbildungen neuer Thierarten, während des Flottcapitains von Kotzebue zweiter Reise um die Welt 1823-1826 gesammelt. Reimer, Berlin

Ferrer J, Moragues G (2001) Contribution a l'etude des représentants américains du genre Trichoton Hope, 1840, avec description de quatre nouvelles espèces (Coleoptera, Tenebrionidae). Bulletin de la Societe Entomologique de France 106:497-518

Ferrer J, Moragues G (2002) Addenda et corrigenda a notre etude sur les representants americains du genre Trichoton Hope Col, Tenebrionidae. Bulletin de la Societe Entomologique 107:230

Grebennikov VV, Scholtz CH (2004) The basal phylogeny of Scarabaeoidea (Insecta: Coleoptera) inferred from larval morphology. Invertebr Syst 18:321-348

Hart CJ, Ivie M (2016) Revision of the genus Diastolinus Mulsant and Rey (Coleoptera: Tenebrionidae). Coleopt Bull 70:485-540
Hayashi N (1966) A contribution to the knowledge of the larvae of Tenebrionidae occurring in Japan (Coleoptera: Cucujoidea). Insecta Matsumurana Suppl. 1:141

Hayashi N (1968) Additional notes on the larvae of Lagriidae and Tenebrionidae occurring in Japan (Coleoptera: Cucujoidea). Insecta Matsumurana, Suppl. 3:12

ICZN (1999) International Code of Zoological Nomenclature, Fourth Edition, adopted by the International Union of Biological Sciences. Int Trust Zool Nomencl Lond xxix $+306 \mathrm{pp}$

Ivie MA, Hart CJ (2016) Redefinition of Diastolinus Mulsant and Rey, with a review of West Indian blapstinoid genera (Coleoptera: Tenebrionidae: Opatrini). Coleopt Bull 70:447-481

Iwan D (1995) Revision of the genus Opatrinus Dejean, 1821 (Coleoptera: Tenebrionidae: Platynotini). Genus 6:1-90

Iwan D (2000) Oviviparity in tenebrionid beetles of the melanocratoid Platynotina (Coleoptera: Tenebrionidae: Platynotini) from Madagascar with notes on the viviparous beetles. Ann Zool 50:15-25

Iwan D (2002) Generic classification of the tribe Platynotini (Coleoptera: Tenebrionidae), with notes on phylogeny. Ann Zool $52: 1-149$

Iwan D (2005) A new species of Clastopus Fairmaire, 1898 from Madagascar, with notes on the known first-stage larvae (Coleoptera: Tenebrionidae: Pedinini: Platynotina). Ann Zool 55:23-27

Iwan D, Banaszkiewicz M (2005) Larvae of the genus Anomalipus Latreille, 1846 (Coleoptera: Tenebrionidae). Ann Zool $55: 375-381$

Iwan D, Bečvár S (2000) Description of the early stages of Anomalipus plebejus plebejulus (Coleoptera: Tenebrionidae) from Zimbabwe with notes on the classification of the Opatrinae. Eur J Entomol 97:403-412

Iwan D, Kamiński MJ (2016) Toward a natural classification of opatrine darkling beetles: comparative study of female terminalia. Zoomorphology 135:453-485

Iwan D, Schimrosczyk D (2008) Description of the larva of Anchophthalmus Gerstaecker, 1854 (Coleoptera: Tenebrionidae: Pedinini), with a key to larvae of Platynotina. Afr Entomol $16: 287-295$

Jack RW (1917) Notes on the larvae, etc., of some Rhodesian Tenebrionidae. S Afr J Nat Hist 1:84-98

Jia L, Yu Y, Zhang J (2014) The indoor biological characteristics of Penthicus (Myladion) alashanica and Eumylada potanini. J Environ Entomol 36:412-418

Jinxia D, Youzhi Yu (2000) On eight species of larvae the tribe Opatrini (Coleoptera: Tenebriondae). J Ningxia Agric Coll 21:51-56

Kamiński MJ (2015) Phylogenetic reassessment and biogeography of the Ectateus generic group (Coleoptera: Tenebrionidae: Platynotina). Zool J Linn Soc 175:73-106

Kamiński MJ, Kanda K, Raś M, Smith AD (2018a) Pythiopina, an enigmatic subtribe of darkling beetles (Coleoptera: Tenebrionidae: Pedinini): taxonomic revision, microtomography, ecological niche models and phylogenetic position. Syst Entomol 43:147-165

Kamiński MJ, Raś M, Steiner WE, Iwan D (2018b) Immature stages of beetles representing the 'Opatrinoid' clade (Coleoptera: Tenebrionidae): an overview of current knowledge of the pupal morphology. Ann Zool 68:825-836

Kamiński MJ, Kanda K, Lumen R, Smith AD, Iwan D (2019) Molecular phylogeny of Pedinini (Coleoptera, Tenebrionidae) and its implications for higher-level classification. Zool J Linn Soc 185:77-97

Kanda K, Pflug JM, Sproul JS, Dasenko MA, Maddison DR (2015) Successful recovery of nuclear protein-coding genes from small insects in museums using Illumina sequencing. PLoS One 10:e0143929

Kanda K, Gomez RA, Van Driesche R, Miller KB, Maddison DR (2016) Phylogenetic placement of the Pacific Northwest 
subterranean endemic diving beetle Stygoporus oregonensis Larson \& LaBonte (Dytiscidae, Hydroporinae). ZooKeys 632:75-91

Keleinikova SI (1961) Towards knowledge of larvae of the subfamily Opatrinae (Coleoptera, Tenebrionidae) of Western Kazakhstan. Sbornik Trudov Zoologicheskovo Muzeya Mgu 8:159-164

Keleinikova SI (1966) Descriptions of larvae of some Palearctic genera of darkling beetles of the tribe Pedinini (Coleoptera, Tenebrionidae). Entomol Obozr 45:589-598

Keleinikova SI (1968) Soil-inhabiting darkling beetle larvae (Coleoptera, Tenebrionidae) in the Soviet fauna. Sbornik trudov Gosudarstvennogo Zoologicheskogo muzeya (pri Moskovskom gosudarstvennom universitete) 11:205-239

Knor IB (1976) Novye dl'a fauny Sovietskogo Soyuza chernotelki (Coleoptera, Tenebrionidae) iz Tuvy. In: Tsherepanov AI (ed). Novosti fauny Sibiri. Novye i maloizvestnye vidy fauny Sibiri. Vypusk 10. Novosibirsk, Nauka, pp 102-109

Knor IB (1977) Description of larvae of the tribe Tentyriini (Coleoptera, Tenebrionidae) from southern Siberia. Entomol Obozr $56: 644-652$

Knor IB (1978) [Darkling beetles (Coleoptera, Tenebrionidae) of the steppe mountain ravines of Tuva.]. Trudy Biologicheskogo Instituta Sibirskoe Otdelenie Akademiy Nauk SSSR: 34

Koch C (1954) Die Tenebrioniden des südlichen Afrikas XV. Revision der Oncotini nov. trib. Opatrinae (Psectropini Kaszab p.p.). Arkiv Zool Stockh 7:1-96

Koch C (1955) The Tenebrionidae of Southern Africa. XXV. New, forgotten or Palearctic genera and species of Opatrinae. Ann Transvaal Mus 22:419-476

Koch C (1956) Exploration du Parc National de l'Upemba. II. Tenebrionidae (Coleoptera, Polyphaga), Opatrinae, first part: Platynotini, Litoborini and Loensini. Bruxelles: Institut des Parcs nationaux du Congo Belge

Lacordaire T (1859) Histoire naturelle des Insectes. Generades Coléoptères ou exposé méthodique et critique de tousles genres proposés jusqu'ici dans ce ordre d'Insectes. Tome Cinquiéme. Librairie Encyclopédeique deRoret. Premiére partie, Paris, pp $1-400$

Lanfear R, Calcott B, Ho SY, Guindon S (2012) PartitionFinder: combined selection of partitioning schemes and substitution models for phylogenetic analyses. Mol Biol Evol 29:1695-1701

Lawrence JF (1991) Coleoptera. pp. 144-298 in Stehr, F. (Ed.), Immature Insects. Vol. 2. Kendall/Hunt, Dubuque, IA. 975 pp

Lawrence JF, Ślipiski A, Seago AE, Thayer MK, Newton AF, Marvaldi AE (2011) Phylogeny of the coleoptera based on morphological characters of adults and larvae. Ann Zool 61:1-217

LeBoeuf J (2002) Crop timeline for cantaloupes, honeydews, and watermelons in California. Report prepared for U.S. Environmental Protection Agency Office of Pesticide Programs Washington, D.C.

Li J, Yu Y, Zhang D (2013) The morphology of the tribe Opatrinilarvae in northern of China. J Agric Sci 34:34-39

Lindeman K (1889) Die schädlichsten Insekten des Tabak in Bessarabien. Bulletin de la Société Impériale des Naturalistes de Moscou. Nouv Sér II: 10-77

Maddison WP, Maddison DR (2016) Mesquite: a modular system for evolutionary analysis, version 3.11. http://mesquiteproject.org

Marcuzzi G, Cravera C (1981) Illustrazione di larve di Coleotteri Tenebrionidi dell-area Caraibica. Quaderni di Ecologia Animale 17:3-11

Matthews EG, Lawrence JF, Bouchard P, Steiner WE, Ślipiński SA (2010) 11.14 Tenebrionidae Latreille, 1802. In: Leschen RAB, Beutel RG, Lawrence JF (eds) Handbook of zoology. A natural history of the phyla of the animal kingdom. Vol IV-Arthropoda: Insecta. Part 38. Coleoptera, Beetles. Vol 2: systematics. Walter de Gruyter, Berlin, pp 574-659
Medvedev GS (1968) Coleoptera. Darkling-beetles (Tenebrionidae), subfamily Opatrinae, tribes Platynotini, Dendarini, Pedinini, Dissonomini, Pachypterini, Opatrini (part) and Heterotarsini. Leningrad: Fauna of USSR, Zhestkokrylye, Vol. 19(2)

Miller MA, Pfeiffer W, Schwartz T (2010) Creating the CIPRES Science Gateway for inference of large phylogenetic trees. Proceedings of the Gateway Computing Environments Workshop (GCE). 14 November 2010, New Orleans, LA. 1-8

Mulsant E (1854) Histoire naturelle des coléoptères de France. Latigènes. L. Maison, Paris

Mulsant E, Rey C (1853) Supplément à la monographie des coléoptères trimères sécuripalpes. Annales de la Société Linnéenne de Lyon (Nouvelle Série) 1:129-333

Mulsant E, Rey C (1854) Essai d'une division des derniers Mélasomes. Mémoires de l'Académie Impériale des Sciences, Belles-Lettres et Arts de Lyon. Classe des Sciences (Nouvelle série) 4:155-332

Nepesova MG (1965) Biology of Opatroides punctulatus Brullé (Coleoptera, Tenebrionidae) and a description of its larvae [in Russian]. Izvestiya Akademii Nauk Turkmenskoi SSR, Seriya Biologicheskikh Nauk 2:57-63

Ogloblin DA, Kolobova AN (1927) Darkling beetles (Tenebrionidae) and their larvae, harmful to agriculture. Trudy Poltavskoy selskochozyaistvennoy opytnoy stanzii 61:1-60 [In Russian]

Papp CS, Pierce HD (1960) Ecological remarks on some tenebrionids connected with stored animal food in the Mojave Desert, California. J Kansas Entomol Soc 33:154-156

Perris E (1877) Larves de Coléoptères. Annales de la Société Linnéenne de Lyon 23, 430 [in French]

Reichardt AN (1936) Zhuki-chernotelki triby Opatrini Palearkticheskoj oblasti [Darkling beetles of the tribe Opatrini of Palearctic region]. Izdatel'stvo AN SSSR, Moskow, Leningrad [in Russian]

Ren G, Yu Y, Yang X (2000) A list of the known darkling beetleslarvae (Coleoptera: Tenebrionidae) from the Mongolia-Xinjiang Region in China. J Hebei Univ 20:1-10

Roberts R (1947) Soil treatment to control Blapstinus wireworms. J Econ Entomol V40(4):571-572

Rojas P (1988) Nota sobre una poblacion de Bycrea villosa Pascoe (Coleoptera: Tenebrionidae) en los detritos de Atta mexicana (F. Smith) (Hymenoptera: Formicidae). Folia Entomol Mex $76: 73-88$

Schiödte JC (1878) De metamorphosi eleutheratorum observation es. Pars X, Tenebrionidaes. 8. Kopenhagen

Schulze L (1962) The Tenebrionidae of southern Africa. XXXIII. Description of the larvae of Gonopus tibialis Fabricius and Gonopus agrestis Fahraeus (Gonopina, sensu Koch 1956). Cimbebasia 5:1-12

Schulze L (1963) The Tenebrionidae of Southern Africa. XXXVIII. On the morphology of the larvae of some Stizopina (Coleoptera: Opatrini). Sci Pap Namib Desert Res Stat 19:1-23

Schulze L (1964) The Tenebrionidae of southern Africa. XXXVI. Descriptive notes and key to the larvae of Zophodes fitzsimonsi Koch, Bantodemus zulu Koch and Quadrideres femineus (Lesne) (Coleoptera: Platynotina s. str.). J Entomol Soc South Afr 26:441-451

Schulze L (1968) The Tenebrionidae of Southern Africa. XLI. Descriptive notes on the early stages of four genera of the tribe Drosochrini (Coleoptera). Ann Transvaal Mus 26:31-51

Schulze L (1969) The Tenebrionidae of Southern Africa. XLII. Description of the early stages of Carchares macer Pascoe and Herpiscus sommeri Solier with a discussion of some phylogenetic aspects arising from the incongruities of adult and larval systematics. Scient Pap Namib Desert Res Stn 53:139-149

Schulze L (1978) The Tenebrionidae of southern Africa. XLV. Description of some larvae of the subgenera Gonopus and Agonopus of the genus Gonopus (Coleoptera). Ann Transvaal Mus 31:1-16 
Skopin NG (1962) [Larvae of the subfamily Pimeliinae (Coleoptera, Tenebrionidae)]. Lichinki podsemeystva Pimeliinae (Coleoptera, Tenebrionidae). Trudy Nauchno-Issledovatelskogo Instituta Zashchity Rastenii Kazakhstanskoy Akademii Selskokhozyastvennykh Nauk 7:191-298

Skopin NG (1964) Die Larven der Tenebrioniden des Tribus Pycnocerini (Coleoptera, Heteromera). Annales de Museé Royal de l'Afrique Centrale, Tervuren, Serie in 8. Sci Zool 127:1-35

Skopin NG (1972) Über einige Tenebrioniden-Larven aus Nepal nebst übersicht der bekanntesten Larven der primitiven Blapsarten (Ins., Coleoptera). Khumbu Himal Innsbruck-München $4: 315-321$

Skopin NG (1978) Tenebrionidae. In: Klausnitzer B (ed) Ordnung coleoptera (larven). W. Junk, The Hague, pp 223-266

Smith AD, Dornburg R, Wheeler QD (2014) Larvae of the genus Eleodes (Coleoptera, Tenebrionidae): matrix-based descriptions, cladistic analysis, and key to late instars. Zookeys 415:217-268

Spilman TJ (1959) Notes on Edrotes, Leichenum, Palorus, Eupsophulus, Adelium, and Strongylium (Tenebrionidae). Coleopt Bull 13:58-64

St. George RA (1930) The discovery of what is possibly the larva of an introduced Tenebrionid, Leichenum variegatum Küst. Proc Entomol Soc Wash 32:122-124

Stamatakis A (2014) RAxML version 8: a tool for phylogenetic analysis and post-analysis of large phylogenies. Bioinformatics 30:1312-1313

Steiner WE Jr (2003) An immigrant darkling beetle new to Hawaii (Coleoptera: Tenebrionidae). Records of the Hawaii Biological Survey for 2002, Part 2: Notes. Bishop Mus Occas Pap 74:40-42

Steiner WE Jr (2004) The first records of Bycrea villosa Pascoe (Coleoptera: Tenebrionidae) in the United States, Central America and Colombia and notes on its association with Leaf-Cutting Ants. Coleopt Bull 58:329-334

Strauss SY, Rudgers JA, Lau JA, Irwin RE (2002) Direct and ecological costs of resistance to herbivory. Trends Ecol Evol 17:278-284

Tschinkel WR (1978) Ovoviviparity in some tenebrionid beetles. Coleopt Bull 32:315-317
Wade JS, Boving AG (1921) Biology of Embaphion muricatum. J Agric Res 22:323-335

Watt J (1974) A revised subfamily classification of Tenebrionidae (Coleoptera). N Z J Zool 11:381-452

Wilcox J, Howland AF (1943) Damage to strawberry fruit by small darkling beetles (Blapstinus spp.). J Econ Entomol 36:116

Xambeu P (1900) Moeurs et métamorphoses des insectes. Annales de la Société Linnéenne de Lyon 49:154

Yu Y, Ren G (1994) Tenebrionid larvae of certain species of the Opatrini tribe from N China (Coleoptera: Tenebrionidae. Entomol Res 1:91-100

Yu Y, Ren G, Fu Z (1993) Key to ground larvae of Tenebrionidae (Coleoptera) in the North of China. J Ningxia Agric Coll 14:71-78

Yu Y, Dai J, Ren G (2000a) The form on seven species of larvae of Gonocephalum (Coleoptera: Tenebrionidae). J Ningxia Agric Coll 21:1-6

Yu Y, Dai J, Ren G (2000b) On the larvae of four species of the genus Monatrum Reichardt in China (Coleoptera: Tenebrionidae). J Hebei Univ 20:79-82

Yu Y, Ren G, Li Yu (2000c) First description of four species tenebrionid-larvae (Coleoptera) from inner Mongolia-Xinjiang Region. J Hebei Univ 20:63-65

Zhang F, Yu Y (2004) Description of five species of the tribe OpatriniLarvae (Coleoptera: Tenebrionidae). J Ningxia Univer (Nat Sci Edit) $25: 4$

Zilkowski BW, Cossé AA (2015) A culture method for darkling beetles, Blapstinus spp. (Coleoptera: Tenebrionidae). J Econ Entomol 108:1010-1013

Publisher's Note Springer Nature remains neutral with regard to jurisdictional claims in published maps and institutional affiliations. 